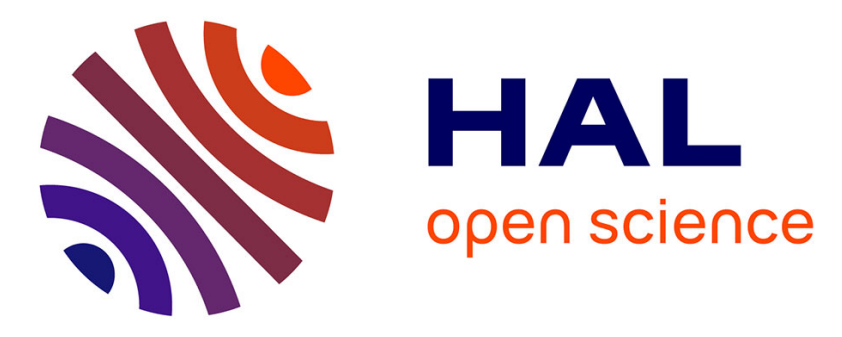

\title{
Marine gateway vs. fluvial stream within the Balkans from 6 to $5 \mathrm{Ma}$
}

\author{
Jean-Pierre Suc, Speranta-Maria Popescu, Damien Do Couto, Georges \\ Clauzon, Jean-Loup Rubino, Mihaela Carmen Melinte-Dobrinescu, Frédéric \\ Quillévéré, Nikola Dumurdžanov, Ivan Zagorchev, Vesna Lesić, et al.
}

\section{To cite this version:}

Jean-Pierre Suc, Speranta-Maria Popescu, Damien Do Couto, Georges Clauzon, Jean-Loup Rubino, et al.. Marine gateway vs. fluvial stream within the Balkans from 6 to 5 Ma. Marine and Petroleum Geology, 2015, 66 (1), pp.231-245. 10.1016/j.marpetgeo.2015.01.003 · hal-01114483

\section{HAL Id: hal-01114483 https://hal.science/hal-01114483}

Submitted on 9 Feb 2015

HAL is a multi-disciplinary open access archive for the deposit and dissemination of scientific research documents, whether they are published or not. The documents may come from teaching and research institutions in France or abroad, or from public or private research centers.
L'archive ouverte pluridisciplinaire HAL, est destinée au dépôt et à la diffusion de documents scientifiques de niveau recherche, publiés ou non, émanant des établissements d'enseignement et de recherche français ou étrangers, des laboratoires publics ou privés. 


\title{
Marine gateway vs. fluvial stream within the Balkans from 6 to 5 Ma
}

\author{
Jean-Pierre Suc ${ }^{1-2}$, Speranta-Maria Popescu ${ }^{3}$, Damien Do Couto ${ }^{4}$, Georges Clauzon ${ }^{5}$, \\ Jean-Loup Rubino ${ }^{6}$, Mihaela Carmen Melinte-Dobrinescu ${ }^{7}$, Frédéric Quillévéré ${ }^{8}$, \\ Jean-Pierre Brun ${ }^{9}$, Nikola Dumurdžanov ${ }^{10}$, Ivan Zagorchev ${ }^{11}$, \\ Vesna Lesic $^{12}$, Dragana Tomić ${ }^{12}$, Dimitrios Sokoutis ${ }^{13-14}$, \\ Bertrand Meyer ${ }^{1-2}$, Rodica Macaleț ${ }^{15}$, Helena Rifelj ${ }^{16}$
}

1, Sorbonne Universités, UPMC Univ. Paris 06, UMR 7193, Institut des Sciences de la Terre Paris (iSTeP), 75005 Paris, France

2, CNRS, UMR 7193, Institut des Sciences de la Terre Paris (iSTeP), 75005 Paris, France

3, GeoBioStratData.Consulting, 69140 Rillieux la Pape, France

4, Section of Earth and Environmental Sciences, University of Geneva, 13 rue des Maraîchers, 1205, Geneva, Switzerland

5, Aix-Marseille University, CNRS, IRD, CEREGE UM34, 13545 Aix-en-Provence, France

6, TOTAL, TG/ISS, CSTJF, Avenue Laribeau, 64018 Pau Cedex, France

7, National Institute of Marine Geology and Geoecology, 23-25 Dimitrie Onciul street, P.O. Box 34-51, 70318 Bucharest, Romania

8, Université Lyon 1, Laboratoire de Géologie de Lyon, Terres, Planètes, Environnement, UMR 5276 CNRS, 27-43 boulevard du 11 Novembre 1918, 69622 Villeurbanne Cedex, France

9, Géosciences Rennes, UMR 6118, Université Rennes 1, 35042 Rennes Cedex

10, Sts. Cyril and Methodius University, Faculty of Mining and Geology, Goce Delčev 89, 2000 Stip, Republic of Macedonia

11, Geological Institute, Bulgarian Academy of Sciences, 1113 Sofia, Bulgaria

12, Republik Geodetic Authority, Department for Geomagnetism and Aeronomy, Bulevar Vojvode Mišića 39, Belgrade, Republic of Serbia

13, Department of Earth Sciences, Faculty of Geosciences, Utrecht University, Budapestlaan 4, PO Box 80021, 3508 Utrecht, The Netherlands

14, Department of Geosciences, University of Oslo, PO Box 1047, Blindern, N-0316 Oslo, Norway

15, National Institute of Hydrology and Water Management, 97 Bucuresti-Ploiesti Road, 013686 Bucharest, Romania

16, Geological Survey of Slovenia, Dimičeva ulica 14, 1000 Ljubljana, Slovenia 


\begin{abstract}
Since the discovery of calcareous nannofossils, dinoflagellate cysts and planktonic foraminifers in deposits from the Dacic Basin, intensive research has been performed in order to evidence which gateway this microplankton used to connect Paratethys and the Mediterranean prior and after the Messinian Salinity Crisis (MSC). Such a gateway is also to be regarded at the origin of successive influxes of Paratethyan organisms (molluscs, ostracods, dinoflagellates) into the Mediterranean Basin ("Lago Mare" events). Observing that the İ stanbul area, usually proposed for this purpose, was inefficient, we examine the succession of marine well-dated pre-MSC and post-MSC deltaic deposits through the Balkans, from northern Greece to southern Romania, that constitutes a reliable candidate for such a marine corridor, the origin of which was caused by the regional tectonic extension. The reconstructed palaeogeography for high sea level episodes that encompassed the MSC clarifies the context of the so-called North Aegean Lake. This marine gateway probably evolved as a powerful river during the peak of the MSC, contributing to the deposition of clastics in the hydrocarbon Prinos Field. A tectonically controlled subsidence to the north and south of the Skopje region caused the closure of such a gateway.
\end{abstract}

Key-words: Mediterranean - Paratethys connections; Messinian Salinity Crisis; Marine microfossils; Fluvial erosion; Balkans corridor.

\title{
1. Introduction
}

The matter of Neogene relationships between the Mediterranean Sea and the former Paratethys, an adjacent brackish basin (Fig. 1A) has been early tackled by Rögl and Steininger (1983) at a time where stratigraphic correlations were insufficiently ensured. They considered a gateway in the area of the İ stanbul area before and after the Messinian Salinity Crisis (MSC), a hypothesis then adopted by Popov et al. (2006). However, the assumption of a gateway or a drainage network through the Balkans was suggested by Hsü (1978) (Fig. 2A) and Hsü et al. (1977, 1978b) (Fig. 2B), respectively. A possible corridor was sought along the Struma/Strymon palaeo-river, but Kojumdgieva (1987) was inconclusive because of the obvious lack of marine or even lacustrine sediments in the Sandanski graben (OgnjanovaRumenova et al., 2007). Such a hypothesis arose from the old concept of a North Aegean Lake (Cvijić, 1911), revisited by Krstić (2006) who studied ostracod faunas. A recent review by Krstić et al. (2012) adopted the idea about a gateway between the Pannonian ("Paludinian" Lake) and the Aegean basins via Morava and Vardar but has overestimated to some extent the territories of the "Aegean Lake" and postulated a not-proven Pliocene connection along the Palaeo-Struma.

An important turnaround in the concept occurred when marine calcareous nannoplankton was discovered in the Dacic Basin (Mărunţeanu and Papaianopol, 1995) within Lower and Upper Pontian deposits ascribed to the reverse C3r palaeomagnetic Chron (Snel et al., 2006a; see Figure 4 for correspondence between global stages and Paratethyan Stages). Calcareous nannoflora of the Lower Pontian sediments belongs to the NN11b Subzone (characterized by the occurrence of Discoaster quinqueramus), that of the Upper Pontian sediments belongs to NN12 Zone (characterized by the occurrence of Ceratolithus acutus) (Snel et al., 2006a). After almost similar results, Clauzon et al. (2005) concluded that high sea-level episodes connected the Mediterranean and Dacic Basin just prior the MSC and just after it, also documented by planktonic foraminifers (Suc et al., 2011). Popescu et al. (2006) showed that 
Mediterranean micro-organisms (calcareous nannofossils, planktonic foraminifers, dinoflagellate cysts) invaded Dacic Basin before $5.4 \mathrm{Ma}$, an age that has been further specified at 5.45 Ma by Bache et al. (2012). This marine water input reached the Dacic Basin significantly before the Euxinian Basin (i.e., the Black Sea; Fig. 1A) where it has been recorded at 5.31 Ma (Popescu et al., 2010). In addition to this time-lag, the absence of Mediterranean - Black Sea connection in the area of İ stanbul since ca. 8 Ma (Suc et al., submitted) also supports a marine gateway through the Balkans, as documented by Bache et al. (2012) (Fig. 2C). As a consequence, a new pattern of crossed exchanges of organisms between the Mediterranean and the Dacic Basin during high sea-level episodes can be tested to explain the episodes of Lago Mare 1 (before the peak of the MSC) and 3 (after the peak of the MSC) in the Mediterranean, as argued by Clauzon et al. (2005), Popescu et al. (2009), Suc et al. (2011), Bache et al. (2012), Bakrač et al. (2012) and Do Couto et al. (2014).

This paper aims (1) to complete the field data sets published in Clauzon et al. (2005), Suc et al. (2011) and Bache et al. (2012) that supports the Balkans marine gateway, and (2) to discuss how this passage was affected by the peak of the MSC.

\section{Methodological approach and geographic area of investigation}

As soon as marine calcareous nannofossils were recorded in the Dacic Basin for a timeinterval encompassing the MSC (Clauzon et al., 2005; Snel et al., 2006a), an approach has been developed for re-visiting the Balkans region that was a strong candidate to have hosted the Mediterranean - Dacic Basin exchange gateway (see above).

This investigation was done following the present-day back to back fluvial networks (Fig. 3): Struma/Strymon and Vardar/Axios towards the Mediterranean Basin, Morava, Timok and Iskar towards the Danube River; the two obvious options for a corridor being via Iskar - Sofia Lake - Struma/Strymon or Morava - Vardar/Axios; in view of the lack of marine or lacustrine Neogene sediments along most of Palaeo-Struma to the north of the Belasitsa horst (Zagorčev, 1992a; Zagorchev, 2007; Ognjanova et al., 2007), we concentrated (Clauzon et al., 2008; Bache et al., 2012) on the second option (Morava-Vardar) where a narrow divide must be noticed in the area of Skopje. In this frame, we searched for:

- calcareous nannofossils because of (1) their worldwide stratigraphic significance regularly reasserted (Martini, 1971; Perch-Nielsen, 1985; Berggren et al., 1995; Raffi et al., 2006), and (2) their ability to be the first invasive indicators of previously isolated basins by marine surface waters where they are living (Winter et al., 1994), and

- pollen grains and dinoflagellate cysts from some localities in order (1) to complete the available dataset (Clauzon et al., 2005; Popescu et al., 2006; Jiménez-Moreno et al., 2007) and (2) to contribute to reconstruct palaeoenvironments.

\section{Data from the Aegean to the Dacic Basin}

Both basins and their drainage areas have been subject of detailed and important studies and numerous publications that will be only partially referred to in the present paper. We restrain mostly to new evidence of utmost importance for the problem of the Balkans corridor. Available plus unpublished data are examined from the South to the North, with a focus on the most significant precisely dated localities, and following the different branches of the socalled North Aegean Lake (Fig. 2).

\subsection{North Aegean area}


The remarkable locality of Akropotamos is located near the Aegean shoreline (locality 4 in Fig. 1B). It is known for a long time because of the occurrence of Messinian gypsums (with NN11 calcareous nannofossils from the intercalated clays; Figs. 5B-C) in a quarry topped by (1) limestones ( $40^{\circ} 47^{\prime} 30.62$ ” N, 24 01' 56.46" E; Steffens et al., 1979; Dertmizakis et al., 1985/1986) and (2) a clastic succession, the silty beds of which being ascribed to the calcareous nannoplankton NN12 Zone (Steffens et al., 1979). The nannoplankton ages have been specified by Snel et al. (2006b) who recorded Ceratolithus acutus and Triquetrorhabdulus rugosus in the silts of the clastic member hence ascribed to the earliest NN12b Subzone (Fig. 4). The issue raised by this section, which does not concern the age as it is confirmed by A. Di Stefano from our sampling (4046' $01.63^{\prime \prime}$ N, 24 01 ' 39.99" E; Fig. $5 \mathrm{H})$, concerns the interpretation of the stratigraphic relationships between the sedimentary units. In Snel et al. (2006b: fig. 3), the section is presented in a vertical log as usually done for boreholes. Indeed, such a drawing covers up the lateral relationships between the units, aiming to instill a continuous transition from Messinian to Zanclean and, as a consequence, to disregard the impact of the MSC. Actually, we observed that the clastic unit is nested of about $70 \mathrm{~m}$ within the evaporitic unit (including the topmost limestones) (Fig. 5B). These units are separated by an erosional surface which can be followed from place to place (e.g.: $40^{\circ} 46^{\prime}$

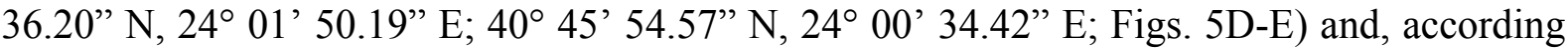
to the above-mentioned ages, is the Messinian Erosional Surface (MES), contemporaneous of the massive drawdown of the Mediterranean Sea level between 5.60 and 5.46 Ma according to Bache et al. (2012). The overlying clastic sediments are those of a Gilbert-type fan delta with all its characteristic constituents (submarine foreset beds and bottomset beds, and subaerial topset beds: Figs. 5B, D-G), attesting a fast marine reflooding (for a detailed description, see: Bache et al., 2012).

In the same area, the MES has also been observed near the statue of the Amphipolis Lion $\left(40^{\circ} 48^{\prime} 08.89^{\prime \prime} \mathrm{N} ; 23^{\circ} 50^{\prime} 30.89^{\prime \prime} \mathrm{E}\right.$; locality 3 in Fig. 1B) where gravely to sandy foreset beds truncate Miocene continental deposits (Figs. 6A-B). Because of their dipping orientation, we consider that the foreset beds belong to a tributary of a large Gilbert-type fan delta, the bottomset beds of which are known for their marine Zanclean malacofauna (Syrides, 1998a). The topset beds, exposed along the road going up the Strymon River, provided a pollen flora typical of Zanclean coastal environments in the region (Table 1; Jiménez-Moreno et al., 2007). This Gilbert-type fan delta is clearly nested within the Miocene deposits that, in several places, provided Paratethyan molluscs (dreisseinids and lymnocardiids) (Syrides, 1998b).

The Prinos hydrocarbon Field (Fig. 1B) lies within a pull-apart basin beneath a thick evaporitic unit at the top of which an erosional unconformity has been revealed (Fig. 7; Proedrou and Sidiropoulos, 1993; Proedrou and Papaconstantinou, 2004). Thick clastic deposits were deposited below and above the evaporitic unit that also contains several thin clastic intercalations. Biostratigraphic data available from Nestos 1 and 2 wells (location 5 in Fig. 1B), located on its northeast edge, indicate (1) the occurrence of the calcareous nannofossil Discoaster quinqueramus between 1030 and $1050 \mathrm{~m}$ bsf (below sea floor) in Nestos 2, and (2) the occurrence of the planktic foraminifer Globorotalia puncticulata between 585 and $600 \mathrm{~m}$ bsf in well Nestos 1 and between 800 and $870 \mathrm{~m}$ bsf in well Nestos 2 (Fig. 7; Sidiropoulos, 1980). In well Nestos 2, the benthic foraminifer Uvigerina rutila, characteristic of the Lower Pliocene (Iaccarino, 1985), has been continuously recorded from 480 to $830 \mathrm{~m}$ bsf, supporting that the sediments immediately overlying the evaporitic unit belong to Zanclean. The underlying evaporitic unit is Messinian in age, as attested by the occurrence in-between of Discoaster quinqueramus (Fig. 7), a calcareous nannofossil species that disappeared at $5.54 \mathrm{Ma}$ (Fig. 4; Raffi et al., 2006). In the Aegean Sea, many seismic profiles document its status of peripheral shallow water basin during the $1^{\text {st }}$ step of the MSC 
(Clauzon et al., 1996; Bache et al., 2012) because of the identification of the MES (Schuster et al., 1978; Hsü et al., 1978a; Anastasakis et al., 2006; Crombez, 2012), well-dated at Site DSDP 378 northward of Crete where it cuts Messinian peripheral evaporites (Hsü et al., 1978a). Accordingly, the erosional unconformity revealed by Proedrou and Sidiropoulos (1993) at the top of the evaporitic unit can be interpreted as the MES (Fig. 7), which was placed at $965 \mathrm{~m}$ in the Nestos 2 section in agreement with biostratigraphic data and pollen content (Jiménez-Moreno et al., 2007).

Near Thessaloniki, at Trilophos (locality 2 in Fig. 1B), we have observed a gently erosional contact separating the grey sands, limestones and clays with Paratethyan molluscs of the Trilophos Formation (Syrides, 1998b) from the underlying reddish continental clays and sands, Late Miocene in age according to mammals (Steffens et al., 1979) (Fig. 6C: 40 $27^{\circ}$ 41.73 " N, 22 $2^{\circ}$ ' 34.94” E). In its uppermost part, the Trilophos Formation (ca. $20 \mathrm{~m}$ in thickness) is marine according to abundant Mactra shells among other marine species (Gillet and Geissert, 1971). Two samples from these beds (Fig. 6D; $40^{\circ} 27^{\prime} 33.65^{\prime \prime}$ N, $22^{\circ} 59^{\prime} 10.96$ " E) provided a diversified calcareous nannoflora with, among other species, Triquetrorhabdulus rugosus and Ceratolithus acutus, which together characterize the early NN12b Subzone (Fig. 4). The gently underlying erosional surface is thus the MES (Fig. 6C). The thin Trilophos Formaton is interpreted as indicating a lagoonal environment deposition affected by a marine incursion. Accordingly, the Trilophos section is a noticeable example of co-occurrence of Paratethyan and marine Mediterranean organisms, as in the Intepe section on the southern shoreline of the Dardanelles Strait (Melinte-Dobrinescu et al., 2009). The coastal environment is also supported by a pollen record, with abundant halophytes (AmaranthaceaeChenopodiaceae) and freshwater plants (Sparganium, Typha), which also points out a dense forest cover back to the delta up to high altitude of the Olympus Mount (Table 1; Biltekin, 2010).

In the Prosilio section (locality 1 in Fig. $1 \mathrm{~B} ; 40^{\circ} 07^{\prime} 57.28^{\prime \prime} \mathrm{N}, 21^{\circ} 56^{\prime} 01.30^{\prime \prime} \mathrm{E}$ ), an erosional surface separates the Lava Member from the overlying Prosilio Member made of sands and conglomerates (Fig. 6E-G; Steenbrink et al., 2006). Regional stratigraphic correlations and datations allowed Steenbrink et al. (2006) to propose a magnetostratigraphy of the section (reminded in Figure 6E). The erosional truncation impacted sediments of the normal Chron C3An.1n. This leads us to believe that this erosional event, even of a relatively mild intensity, is not local but probably corresponds to the erosional episode caused by the peak of the MSC (Figs. 4). The overlying Tomea Eksi Member shows near its top a palaeomagnetic reversal from Chron $\mathrm{C} 3 \mathrm{r}$ to the normal Chron $\mathrm{C} 3 \mathrm{n} .4 \mathrm{n}$ that corresponds to the earliest Zanclean (Streenbrink et al., 2006). Marine fish remains from the Mugilidae family have been recorded in the middle part of the Prosilio Member that indicates a marine incursion in the area (M. Böhme and A. Ilg, in litteris).

Karistineos and Georgiades-Dikeoulia (1985-1986) established the presence of marine Pliocene in the Serres Basin (location 6 in Fig. 1B) on the basis of some molluscs such as Pecten benedictus and Ostrea lamellose. They described a prograding deltaic context including some brackish layers with Paratethyan molluscs (i.e., the so-called "Choumnikon beds"; see also: Syrides, 1998b). Unfortunately, relationships between the constituents of the Pliocene deltaic system remained unclear. Road works allowed us to observe in 2009 newly exposed sections showing the obvious nesting of the Pliocene deltaic coarse clastic deposits within the Miocene piedmont of the Vrondou Mount (Figs. 8A-B). There (41 ${ }^{\circ} 08^{\prime} 58.94$ " N, $23^{\circ} 32^{\prime} 13.48^{\prime}$ E), near Kato Metochi (Fig. 8A), foreset beds of a sigmoid sedimentary construction, although broken by small transverse faults indicated by Psilovikos and Karistineos (1986), show that they belong to a Gilbert-type fan delta (Fig. 8C; Bache et al., 2012). These foreset beds were displayed by Karistineos and Georgiades-Dikeoulia (19851986) in photographs of their figures 5 and 6 despite a description as cross bedding sediments. 
The erosional contact of the foreset beds on the Miocene piedmont deposits was exposed at the same place (Fig. 8D) and refers to the MES (Fig. 8D). Bottom set beds of the Kato Metochi Gilbert-type fan delta have been sampled in a nearby place $\left(41^{\circ} 08^{\prime} 52.17^{\prime \prime} \mathrm{N}, 23^{\circ}\right.$ 32 ' 14.46" E; Fig. 8E) where lignites interfinger to clays and silts. They did not provide any calcareous nannofossil, probably because of their upstream location within the Gilbert-type fan delta. Karistineos and Georgiades-Dikeoulia (1985-1986) pointed out the occurrence of a debris-flow (with granite blocks) at the base of the Pliocene marine sediments. They correspond to the commonly observed coarse deposit marking around the Mediterranean the post-MSC marine reflooding (see: Bache et al., 2012), as we noticed also in the nearby Sidirókastro locality where such debris-flows are covered by large olistoliths made of marble, that recalls the situation in the Roussillon Basin (Clauzon et al., submitted). A pollen analysis was realized on samples from the area of Kato Metochi and ascribed to the Late Miocene according to a poor and inconclusive micromammal fauna (Karistineos and Ioakim, 1989). As the stratigraphic location of these pollen records is unclear, we performed the palynological analysis of a clayey sample from the above mentioned bottomset beds of the Kato Metochi Gilbert-type fan delta: it indicates a coastal swamp with Taxodiaceae in a regional forested context up to elevated altitudes (Table 1).

According to these new results and the synthesis of available data, we can conclude that the MES is present in the North Aegean area, less marked in the Vardar/Axios River drainage basin than in the Struma/Strymon River one, where thick and large Gilbert-type fan deltas developed as a result of the sudden marine reflooding which ended the MSC. However, several localities contain in their post-MSC deposits both Paratethyan molluses and marine Mediterranean organisms (molluscs and/or calcareous nannofossils).

\subsection{The intra-Balkans area}

We re-visited the Pliocene of the Skopje region (locality 8 in Fig. 1B; Dumurdanov et al., 2005) where we evidenced and mapped near Dračevo a Gilbert-type fan delta nested within the basement to the South and Upper Miocene sediments to the North (Fig. 9A; Clauzon et al., 2008). Since this finding, after the record of calcareous nannofossils with a large biostratigraphic range in the bottomset beds of the Dračevo Gilbert-type fan delta, new researches for microfossils resulted in the record of Ceratolithus acutus among other species near Batinci $\left(41^{\circ} 55^{\prime} 09.40^{\prime \prime} \mathrm{N}, 21^{\circ} 27^{\prime} 39.10^{\prime \prime} \mathrm{E}\right)$, which confirms the post-MSC age of the sediments (Fig. 9D). The three constituents of the sedimentary system (for more details, see: Bache et al., 2012), i.e. the foreset beds (e.g., Fig. 9C), bottomset beds (e.g., Fig. 9D) and topset beds (e.g., Fig. 9E) are exposed in several places. There, we observed two successive marine-continental transitions (vertical passage from foreset beds to topset beds) (Fig. 9B). Such a peculiarity is known in the Roussillon Basin (S. France) and results from a sea-level rise after the marine reflooding of the Mediterranean Basin (Clauzon et al. submitted). In the northern part of the Gilbert-type fan delta, the topset beds include reworked travertine blocks (Fig. 9E). In several localities, the travertine tops the Upper Miocene sediments and is very close to the erosional contact with the Pliocene deposits (i.e. the MES) (Clauzon et al., 2008). Accordingly, this travertine may be considered as the spring deposit at the time of Messinian erosion. The Dračevo Gilbert-type fan delta was developed in the Messinian valley of the Markova River, a southern tributary of the Vardar River. Because of the weak Quaternary fluvial erosion in this short lateral valley, the Dračevo Gilbert-type fan delta constitutes the larger remaining evidence of the MSC in the middle part of the Balkans.

Between Serres and Skopje, only one area is designated with almost continuous deposits ascribed to Pliocene between Štip and Strumica (locality 7 in Figure 1B; Dumurdzanov et al., 2004, 2005). There, near the Lakavica hamlet (Fig. 10A), one may observe a succession of SE prograding (probably subaqueous) clayey, sandy and conglomeratic deposits ( $41^{\circ} 38^{\prime} 53.16^{\prime \prime}$ 
N, 22 ${ }^{\circ} 13^{\prime} 09.62^{\prime \prime}$ E; Figs. 10B-C), then of aggrading (probably continental) sandy, loamy and conglomeratic deposits $\left(41^{\circ} 38^{\prime} 40.64 " \mathrm{~N}, 22^{\circ} 14 ' 41.55 " \mathrm{E}\right.$; Fig. 10E). The transition between the prograding and aggrading deposits is well exposed $\left(41^{\circ} 38^{\prime} 38.82^{\prime \prime} \mathrm{N}, 22^{\circ} 13^{\prime}\right.$ 29.21" E; Fig. 10D). Despite several attempts, we did not find calcareous nannofossils either palynomorphs (pollen grains or dinoflagellate cysts) in the clays of the prograding body. Dumurdzanov et al. (2005) showed that these deposits unconformably overlie the Late Miocene ones dated by diatom floras. As a consequence, in spite of no direct dating, we consider the Lakavica deposits as a reliable candidate of Pliocene marine connection between the Skopje and Serres regions.

In the surrounding area of Niš (locality 9 in Fig. 1B), the Gabrovačka locality (Fig. 11A) shows exposed clays and conglomerates. This series, which unconformably lies over schistose basement and Lower-Middle Miocene deposits, is considered Lower Pliocene in age according to floral elements (Pavlovic, 1985; Kräutner and Krstić, 2003). We sampled these deposits in two localities: the Gabrovačka Reka clays (43 $18^{\circ}$ '09.10" N, $21^{\circ} 55^{\prime} 25.80^{\prime \prime} \mathrm{E}$; Fig. 11B) provided calcareous nannoplankton with, among several species, Triquetrorhabdulus rugosus and Ceratolithus acutus, attesting ascription to the NN12b Subzone (Bache et al., 2012; Fig. 4); clays from the Gabrovačka stadium were barren $\left(43^{\circ} 18^{\prime}\right.$ $00.50^{\prime}$ N, $21^{\circ} 55^{\prime} 12.60^{\prime}$ E; Fig. 11C). It has been concluded that these clays and the overlying fluvial conglomerate (Fig. 11D) belong to a small deltaic system adjacent to the Nišava River (Fig. 11A), itself tributary of the Morava River (Bache et al., 2012).

These data show that deltaic deposits of post-MSC age with marine incursions (NN12b calcareous nannoplankton Subzone; Fig. 4) are nested within older rocks (basement or Miocene) in the central Balkans along the Vardar and Morava drainage networks.

\subsection{The Dacic Basin}

Clauzon et al. (2005) and Suc et al. (2011) evidenced post-MSC Gilbert-type fan deltas in the area of Turnu Severin (localities 11 and 12 in Fig. 1B). Such thick deposits are separated from older sediments or the basement by a strong erosional surface identified as the MES (Clauzon et al., 2005; Leever et al., 2010; Suc et al., 2011). This convergent system of two Gilbert-type fan deltas is a perfect example of a sedimentary succession in subaqueous conditions of selected terrigenous materials, from coarse conglomerates to sands then clays, deposited with a sedimentary dip within a relatively deep available space resulting from the Messinian fluvial erosion (Fig. 12A-D). Its ascription to the calcareous nannoplankton NN12b Subzone is unequivocally established in several localities where bottomset beds are narrowly interlocked with sandy to gravelly foreset beds (Fig. 12E; Suc et al., 2011). The "traditional upper Sarmatian age" of the Gura Vaii conglomerates (i.e., our foreset beds) cannot be supported (Jipa and Olariu, 2013; Stoica et al., 2013) without careful fieldwork along the MES because there is some risk to inadvertently cross it.

An upper Badenian - early Sarmatian (i.e. Serravallian) pollen flora is available in the close area of Gura Vaii, at Valea Morilor (Jiménez-Moreno, 2005; Jiménez-Moreno et al., 2007) and can be compared to the Hinova one (Figs. 1B, 12A), ascribed to the latest Messinian earliest Zanclean according to calcareous nannoplankton, magnetostratigraphy and cyclostratigraphy (Popescu et al., 2006). The Valea Morilor pollen flora includes abundant pollen grains of Engelhardia with many other tropical and subtropical plants (Euphorbiaceae, Mussaenda type, Rubiaceae, Theaceae, Arecaceae, Sapotaceae, Distylium, Rhodoleia, Platycarya, Rhoiptelea). These thermophilous elements are not present at Hinova where Engelhardia is poorly represented. There are the usual differences between upper Badenian early Sarmatian (i.e., Serravallian) and early Zanclean pollen floras in the region (JiménezMoreno et al., 2007). 
At last, the clarification done by Suc et al. (2011) concerning the misapprehension of the biostratigraphic and stratigraphic data from Hinova by Krijgsman et al. (2010), was ignored by Stoica et al. (2013). The pre- and post-MSC marine incursions by Mediterranean waters in the Dacic Basin are validated by the data published by Clauzon et al. (2005), Snel et al. (2006a), and Suc et al. (2011) including planktonic foraminifers.

\section{DISCUSSION}

We successively discuss in which context the proposed gateway through the Balkans may have occurred, which way did it follow and how did it probably evolve during the peak of the MSC. We also search for the possible relationships with the primary proposed hypotheses in the area (Figs. 2A-B; Hsü, 1978; Hsü et al., 1977, 1978b). However, we start with a clarification concerning reliability of calcareous nannofossil biostratigraphy.

\subsection{Reliability of Ceratolithus acutus as marker of the Mediterranean reflooding}

Some post-MSC sediments have been dated by the occurrence, among others, of the calcareous nannofossil Ceratolithus acutus. This species, easily recognizable, has a very short duration of life (5.345 - 5. 04 Ma; Fig. 4; Raffi et al., 2006), which makes it an excellent biostratigraphic marker of the post-MSC marine reflooding of the Mediterranean Basin. However, it is indicated as rare in the Mediterranean (Castradori, 1998; Di Stefano and Sturiale, 2010). Its scarcity encouraged Grothe et al. (2014) to discredit its significance as a global biostratigraphic fine marker, although it has been recorded by several specialists in many localities around the Mediterranean and peripheral Paratethyan basins (e.g.: Braga et al., 2006; Snel et al., 2006a, 2006b; Soria et al., 2008; Melinte-Dobrinescu et al., 2009; Popescu et al., 2010; Suc et al., 2011; Cornée et al., 2014). According to their stratigraphic position, all these records immediately followed the post-MSC first inflow of surface marine waters in a Mediterranean peripheral basin or in a Paratethyan sub-basin, which occurred at 5.46 Ma, i.e. prior to the Zanclean Global boundary Stratotype-Section and Point (for detail, see: Bache et al., 2012, and references therein). This neo-species may have benefited from (1) the rush of surface waters, and (2) the missing biological competition in a newly invaded space of life. In this way, the contradiction could be solved between relatively frequent occurrences of Ceratolithus acutus in shallow peripheral deposits and its scarcity in deep-water sediments.

\subsection{Context of a gateway through the Balkans}

Occurrence of Paratethyan organisms in the northern Aegean and evidence of marine Mediterranean species in the Dacic Basin before and after the MSC (prior to their arrival in the Black Sea) led us to explore first the most direct way via the Sofia Basin (Kamenov and Kojumdgieva, 1983) and the Blagoevgrad, Simitli and Sandanski grabens along the Struma River (Fig. 1B). This prospect was encouraged by the occurrence of few marine dinoflagellate cysts in the earliest Dacian of the Ravno Pole borehole drilled in the eastern part of the Sofia Basin (Drivaliari, 1993; Jiménez-Moreno et al., 2007). However, diatoms from the C14 Katina borehole drilled near Sofia do not document any marine influence during the Pontian and early Dacian (Ognjanova-Rumenova et al., 2008). The record of scarce dinoflagellate cysts at Ravno Pole must thus be considered as a reworking. Field observations in the grabens along the Struma River established that no marine influx reached the area (Kojumdgieva, 1987; Zagorčev, 1992a; Spassov et al., 2006; Zagorchev, 2007), as also stated by diatoms (Ognjanova-Rumenova, 2006; Ognjanova et al., 2007). Thus, no passage may be supported along the Struma River system (Fig. 3). Similar field investigations were realized from Prilep 
to Ptolemais (Pelagonia Basin) and in the Ohrid Lake that came to the same conclusion, also supported by the diatom records (Ognjanova-Rumenova, 2005, 2006).

Considering the above-described localities with post-MSC marine sediments, we propose a course for the gateway through the Balkans following as much as possible the present-day major fluvial systems shown in Figure 3 (Strymon, Vardar, Morava, Timok; Fig. 13). Three areas are nowadays relatively elevated on the corresponding altimetric profile (Fig. 14): they are the divides delimiting their respective fluvial networks, respectively at $443 \mathrm{~m}$ (A), $437 \mathrm{~m}$ (B) and $602 \mathrm{~m} \mathrm{(C)} \mathrm{in} \mathrm{altitude.} \mathrm{So} \mathrm{few} \mathrm{moderately} \mathrm{high} \mathrm{points} \mathrm{along} \mathrm{a} \mathrm{profile} \mathrm{uplifted} \mathrm{of} 200-$ $300 \mathrm{~m}$ on the whole support the old age of the fluvial networks as inheritance of the Aegean Lake system, as suggested by Zagorchev (2007) for the southern part of the Balkans.

The present-day altitude envelope of the marine-continental transition (MCT) (i.e., the Zanclean seashore) in the six deltaic systems observed along the profile shows an arching that is homothetic to the altimetric profile of the major fluvial systems (Fig. 14). This indicates that the Zanclean seashore has been deformed since the deposition of the deltaic systems. Along most of the profiles, from Turnu Severin and Lakavica, the altitude difference between the MCTs and the closest river profiles is lower than $130 \mathrm{~m}$. Conversely, close to the Strymon Basin the altitude difference reaches values as high as $240 \mathrm{~m}$ (Serres) and $250 \mathrm{~m}$ (Akropotamos). As the whole region underwent extension since the Pliocene (Zagorčev, 1992a, 1992b; Burchfiel et al., 2000; Westaway, 2006; Brun and Sokoutis, 2007), it cannot be considered that the highest MCT altitudes (Lakavica and Skopje) remained unchanged since the Zanclean. However, taking these highest MCT altitudes as a reference, it is especially relevant to discuss the tectonic meaning of the lowest MCT altitudes toward the Pannonian Basin and the Aegean. Toward the North, the $130 \mathrm{~m}$ altitude difference between the Turnu Severin MCT and the Danube River could be entirely due to fluvial incision due to the ongoing subsidence of the Pannonian Basin (Csato et al., 2013) whereas the 100-160 m altitude difference between Lakavica-Skopje and Nis-Turnu Severin is more likely due to moderate extension (Dumurdzanov et al., 2005). Toward the Southeast, the altitude difference between the Serres-Akropotamos MCT and Strymon River that reaches up to $280 \mathrm{~m}$ is related to post-Zanclean extension in the onshore and offshore basins of Strymon and Orfanos, respectively. These basins located along the boundary between the Southern Rhodope Core Complex and the Chalkidiki Block occurred in clockwise rotation (Brun and Sokoutis, 2007), as documented by palaeomagnetism (Dimitriadis et al., 1998). The Chalkidiki Block, which underwent a bulk rotation of $30^{\circ}$ since the Eocene, still rotated by $11^{\circ}-13^{\circ}$ since the Pliocene coeval with a 10 to $15 \mathrm{Km}$ of extension in the Strymon Basin. Whereas it is difficult to quantify the amount of extension in the Orfanos Basin, it must be noted that this basin displays an extremely thick post-Messinian depocenter up to 3,000 m (see Fig. 15 in Brun and Sokoutis, 2007).

In summary, the gateway through the Balkans has been controlled by the extensional tectonics that affected the region from the early Late Miocene to the Late Pliocene, i.e. from ca. 10 to $4 \mathrm{Ma}$, and created new basins on top of the recently exhumed metamorphic and plutonic rocks. The evolution of this Balkans corridor and, in particular, its forthcoming closure, which created obstacles for the free exchange of marine waters between the Paratethys realm and the Mediterranean, apparently resulted since the Zanclean from tectonically controlled subsidence to the North, toward the Pannonian Basin, and to the Southeast, toward the North Aegean.

Is it possible that two opposed marine branches have independently existed, a northern one linked to the Dacic Basin, a southern one linked to the Aegean Sea? In such a palaeogeographic context, the marine waters should have penetrated into the Dacic Basin via the Euxinian Basin (i.e., the Black Sea; Fig. 1A) that is contradicted by (1) the older age of post-MSC marine incursion in the Dacic Basin than in the Black Sea (Popescu et al., 2006, 
2010), (2) the absence of an outlet into the Black Sea for the Palaeo-Tisza River during the peak of the MSC that did not morphologically favoured a marine invasion (Clauzon et al., 2005; Suc et al., 2011), and (3) the barrier of the İstanbul area which probably isolated the Aegean Sea from the Black Sea (Melinte-Dobrinescu et al., 2009; Suc et al., submitted). Accordingly, we take into account a marine gateway that crossed the Balkans region, of which few remains are today perceptible (Fig. 13).

For most of them, the deltaic deposits that constitute these remains belong to adjacent branches of the post-MSC marine gateway, as shown by the direction of their prograding sedimentation. They have been protected from the Quaternary erosion. Only the foreset beds of Turnu Severin and the deposits of Lakavica display an axial progradation. They thus benefited from an exceptional preservation.

\subsection{Palaeogeographic evolution of the Balkans corridor between 6 and $5 \mathrm{Ma}$}

Marine species of calcareous nannoplankton and/or dinoflagellate cysts have been recorded in the late Pannonian - early Pontian of three localities of the Pannonian Basin (Malunje, Krašić, Krajačići; Fig. 1A), i.e. between 8 and 7 Ma (Kovačić et al., 2004). The inferred connection with the Mediterranean Sea was defined by Popescu et al. (2009) as a western branch of the Balkans corridor between Niš and Belgrade, supported by regional geological maps (see: Kräutner and Krstić, 2003). The marine influence was thus felt up to the western extremity of the Pannonian Basin (in the Mura-Zala Basin; Fig. 1A) where brackish ostracods became momentarily predominant in the late Pontian deposits before being replaced by freshwater species (Stevanović and Škerlj, 1989), indicating a short lasting brackish water impulse. At that time, i.e. prior to the MSC, the Balkans corridor branched northward of Niš in direction of the Pannonian and Dacic basins, respectively (for detail, see: Popescu et al., 2009).

During the sea-level drop of the Mediterranean (peak of the MSC: 5.60 - 546 Ma; Fig. 4; Bache et al., 2012), fluvial erosion prevailed up to the northern part of the Pannonian Basin (Csato et al., 2007, 2013). The peri-Carpathian Palaeo-Tisza River deeply cut the Iron Gates (Fig. 1B; Clauzon et al., 2005; Leever et al., 2010; Suc et al., 2011) and possibly continued within the former corridor in direction of the Aegean Basin, collecting a lot of tributaries and draining the residual Pannonian and Dacic lakes. Abundant clastics have been transported by the Palaeo-Struma and Palaeo-Mesta rivers into the Serres graben, and farther south, towards the North Aegean trough (Zagorčev, 1992a, 1992b; Zagorchev, 2007). Such a phenomenon could have been at the origin of clastics that were deposited just above the MES in the Prinos Field (Fig. 7; Proedrou and Sidiropoulos, 1993). Prinos evaporites may also have experienced a similar event, but of less amplitude, during the first lowering in sea level of the MSC (5.971 $-5.60 \mathrm{Ma}$ ), that would explain the clastics intercalations (Fig. 7; Proedrou and Sidiropoulos, 1993).

As estimated by Bache et al. (2012), the Dacic Basin reconnected with the Aegean Sea at $5.45 \mathrm{Ma}$, just after the marine reflooding of the Mediterranean Basin. The high sea-level reconnection allowed crossed exchanges of organisms: dinoflagellates, ostracods and molluscs invaded the Aegean Sea and then the Mediterranean transported by surface water current $\left(3^{\text {rd }}\right.$ Lago Mare event; see: Do Couto et al., 2014), while foraminifers, calcareous nannoplankton and dinoflagellates entered the Dacic Basin using a subsurface reverse current (Clauzon et al., 2005). Influence of the invading marine waters into the Dacic Basin probably reached the westernmost part of the Pannonian Basin where brackish ostracods were again recorded in the Mura-Zala Basin (Fig. 1A; Stevanović and Škerlj, 1989). The marine influxes reached the Black Sea at 5.31 Ma (Popescu et al., 2010; Bache et al., 2012).

It is possible to hypothesize that lagoons and lakes developed around the Balkans corridor during episodes of connection at high sea level, giving a sense to the so-called North Aegean 
Lake. Some of these scattered lakes may have been filled by brackish waters, providing another example of coeval nearby brackish (with dreisseinids, lymnocardiids and ostracods) and marine (with calcareous nannofossils) environments as evidenced by Do Couto et al. (2014) in southern Spain.

According to Mărunţeanu and Papaianopol (1998) and their calcareous nannoplankton investigations in the Dacic Basin, intermittent connections between the Mediterranean Sea and Dacic Basin may have existed up to $4-3$ Ma (Romanian Stage; Fig. 4). Using geochemistry, Sprovieri et al. (2008) observed the inflow of Paratethyan low salinity waters into the Mediterranean from the Tortonian up to the Late Pliocene, except for the MSC duration. They hypothesized a Mediterranean - Paratethys connection during this time interval. The occurrence of Spiniferites cruciformis, a Paratethyan dinoflagellate cyst, at 4.2 Ma at Ptolemais (Fig. 1B; Kloosterboer-van Hoeve et al., 2001) may be explained by water exchanges through the Balkans corridor. The search for calcareous nannofossils at Site 380 (SW Black Sea) evidenced two sets of discontinuous invasions (Popescu et al., 2010): (1) from 5.31 to $4 \mathrm{Ma}$, expected via the Balkans corridor and the Dacic Basin (Bache et al., 2012); (2) from 2 to $0.9 \mathrm{Ma}$, possibly via the Marmara Sea formed since the propagation of the North Anatolian Fault (Armijo et al., 1999, 2002; Karakaş, 2012) and occasional flows over a proto-Bosphorus sill.

At last, propagation of the North Anatolian Fault into the Aegean Basin induced a new tectonic style resulting in the depression of the North Aegean Trough (Armijo et al., 1996; Westaway, 2006) that probably deepened the Prinos peripheral evaporitic series. This crucial geodynamic change probably closed the Balkans corridor.

\section{CONCLUSION}

This synthesis of the available data on the Late Neogene deposits from the North Aegean Sea to the Dacic Basin emphasizes the impact of the MSC and of the subsequent marine reflooding. Before field and micropalaeontological investigation of the Balkans, Mediterranean marine and Paratethyan brackish organisms were both identified on the North Aegean coastline and in the Dacic Basin. Intermediate significant localities were found in Skopje and Niš while a passage over the İstanbul area was discarded.

It is concluded that a marine gateway crossed the Balkans region before the MSC thanks to a propitious extensional tectonic context. Its closure resulted from tectonically controlled subsidence to the north and south of the Skopje region, respectively. Such a gateway gives sense to the so-called North Aegean Lake: a mass of small lagoons and lakes probably surrounding the corridor during the high sea-level phases. During the MSC and particularly during its paroxysm, it was cut by fluvial erosion which probably originated from the Iron Gates and resulted in (1) transport of clastics in the North Aegean, and (2) making it easier to be flooded by marine waters at $5.46 \mathrm{Ma}$. The present-day dense and close fluvial networks of the region remember this corridor. At last, it appears essential to recall the importance of palaeogeographic reconstructions to decipher the Messinian Salinity Crisis.

\section{ACKNOWLEDGEMENTS}

Georges Clauzon, who passed away in March, 2013, actively participated to the field trips in the region with most of us. M. Böhme and A. Ilg are acknowledged for information on fossil fishes from the Prosilio section and for arousing our interest in erosional surfaces in this sedimentary succession. A. Di Stefano analysed our samples from the Akropotamos section. 
The main part of fieldwork and micropalaeontological analyses was realized during the ANREGEO Project that provided a significant financial support. Two anonymous referees significantly contributed to improve this manuscript.

\section{References}

Anastasakis, G., Piper, D.J.W., Dermitzakis, M.D., Karakitsios, V., 2006. Upper Cenozoic stratigraphy and paleogeographic evolution of Myrtoon and adjacent basins, Aegean Sea, Greece. Mar. Petrol. Geol. 23, 353-369.

Armijo, R., Meyer, B., Hubert, A., Barka, A., 1999. Westward propagation of the North Anatolian fault into the northern Aegean: Timing and kinematics. Geology 27(3), 267270.

Armijo, R., Meyer, B., King, G.C., Rigo, A., Papanastassiou, D., 1996. Quaternary evolution of the Corinth Rift and its implications for the Late Cenozoic evolution of the Aegean. geophys. Journ. Intern. 126(1), 11-53.

Armijo, R., Meyer, B., Navarro, S., King, G., Barka, A., 2002. Asymmetric slip partitioning in the Sea of Marmara pull-apart: a clue to propagation processes of the North Anatolian Fault? Terra Nova 14, 80-86.

Bache, F., Popescu, S.-M., Rabineau, M., Gorini, C., Suc, J.-P., Clauzon, G., Olivet, J.-L., Rubino, J.-L., Melinte-Dobrinescu, M.C., Estrada, F., Londeix, L., Armijo, R., Meyer, B., Jolivet, L., Jouannic, G., Leroux, E., Aslanian, D., Dos Reis, A.T., Mocochain, L., Dumurdžanov, N., Zagorchev, I., Lesić, V., Tomić, D., Çağatay, M.N., Brun, J.-P., Sokoutis, D., Csato, I., Ucarkus, G., Çakir, Z., 2012. A two-step process for the reflooding of the Mediterranean after the Messinian Salinity Crisis. Bas. Res., 24,125153.

Bakrač, K., Koch, G., Sremac, J., 2012. Middle and Late Miocene palynological biozonation of the south-western part of Central Paratethys (Croatia). Geologia Croatica 65(2), 207222.

Berggren, W.A., Kent, D.V., Swisher III, C.C., Aubry, M.-P., 1995. A revised Cenozoic geochronology and chronostratigraphy. In: Berggren,W.A., Kent, D.V., Aubry, M.-P., Hardenbol, J. (Eds.), Geochronology, Time Scales and Global Stratigraphic Correlation: A Unified Temporal Framework for an Historical Geology. Special Publication - Society of Economic Paleontologists and Mineralogists 54, pp. 141-212.

Biltekin, D., 2010. Vegetation and climate of North Anatolian and North Aegean region since $7 \mathrm{Ma}$ according to pollen analysis (PhD Thesis). Univ. Lyon 1 and İstanbul, p. 136.

Braga, J.C., Martín, J.M., Riding, R., Aguirre, J., Sánchez-Almazo, I.M., Dinarès-Turell, J., 2006. Testing models for the Messinian salinity crisis: The Messinian record in Almería, SE Spain. Sedim. Geol. 188-189, 131-154.

Brun, J.-P., Sokoutis, D., 2007. Kinematics of the Southern Rhodope Core Complex (North Greece). Int. J. Earth Sci. 96, 1079-1099.

Burchfiel, C.B., Nakov, R., Tzankov, Tz., Royden, L., 2000. Cenozoic Extension in Bulgaria and Northern Greece: the Northern Part of the Aegean Extensional Regime. Geol. Soc. London Spec. Publ. 173, 325-352.

Castradori, D., 1998. Calcareous nannofossils in the basal Zanclean of the Eastern Mediterranean Sea: remarks on paleoceanography and sapropel formation. In: Robertson, A.H.F., Emeis, K.-C., Richter, C., Camerlenghi, A. (Eds.), Proceedings of the Ocean Drilling Program, Scientific Results vol. 160, pp. 113-123.

Clauzon, G., Le Strat, P., Duvail, C., Do Couto, D., Suc, J.-P., Molliex, S., Bache, F., Besson, D., Lindsay, E.H., Opdyke, N.D., Rubino, J.-L., Popescu, S.-M., Haq, B.U., Gorini, C., 
submitted. The Roussillon Basin (S. France): a case-study to distinguish local from regional events between 6 and 3 Ma. Mar. Petrol. Geol. this volume.

Clauzon, G., Suc, J.-P., Dumurdžanov, N., Melinte-Dobrinescu, M.C., Zagorchev, I., 2008. The Pliocene Gilbert-type fan delta of Dračevo (Skopje area, Republic of Macedonia): Paleogeographic inference. Geol. Macedonica 2, 21-28.

Clauzon, G., Suc, J.-P., Gautier, F., Berger, A., Loutre, M.-F., 1996. Alternate interpretation of the Messinian salinity crisis: Controversy resolved? Geology 24(4), 363-366.

Clauzon, G., Suc, J.-P., Popescu, S.-M., Mărunţeanu, M., Rubino, J.-L., Marinescu, F., Melinte, M.C., 2005. Influence of the Mediterranean sea-level changes over the Dacic Basin (Eastern Paratethys) in the Late Neogene. The Mediterranean Lago Mare facies deciphered. Bas. Res. 17, 437-462.

Cornée, J.-J., Münch, P., Melinte-Dobrinescu, M., Ben Moussa, A., Quillévéré, F., Drinia, H., Azdimousa, A., Ouazani Touhami, A., Merzeraud, G., Fauquette, S., Corini, M., Moissette, P., Feddi, N., 2014. The Early Pliocene reflooding in the Western Mediterranean: New insights from the rias of the Internal Rif, Morocco. C. R. Geoscience 346, 90-98.

Crombez V., 2012. Evolution cénozoïque des basins sédimentaires de la mer Egée (Grèce). Mémoire d'Ingénieur Géologue, Institut Polytechnique LaSalle Beauvais, 130 pp.

Csato, I., Granjeon, D., Catuneanu, O., Baum, G.R., 2013. A three-dimensional stratigraphic model for the Messinian crisis in the Pannonian Basin, eastern Hungary). Bas. Res. 25, 121-148.

Csati, I., Kendall, C.G. St C., Moore, P.D., 2007. The Messinian problem in the Pannonian Basin, Eastern Hungary - Insights from stratigraphic simulations. Sedim. Geol. 201, 111140.

Cvijić, J., 1911. L'ancien lac égéen. Ann. Géogr. 20, 111, 233-259.

Dertmizakis, M.D., Georgiades-Dikeoulia, E., Velitzelos, E., 1985/1986. Ecostratigraphic observations on the Messinian deposits of Akropotamos area (Kavala, N. Greece). Ann. Géol. Pays Hellén. Ser. 1, 33, 367-376.

Dimitriadis, S., Kondopoulou, D., Atzemoglou, A. 1998. Dextral rotation and tectonomagmatic evolution of the southern Rhodope and adjacent regions (Greece). Tectonophysics 299,159-173.

Di Stefano, A., Sturiale, G., 2010. Refinements of calcareous nannofossil biostratigraphy at the Miocene/Pliocene Boundary in the Mediterranean region. Geobios 13, 5-20.

Do Couto, D., Popescu, S.-M., Suc, J.-P., Melinte-Dobrinescu, M.C., Barhoun, N., Gorini, C., Jolivet, L., Poort, J., Jouannic, G., Auxietre, J.-L., 2014. Lago Mare and the Messinian Salinity Crisis: Evidences from the Alboran Sea (S. Spain). Mar. Petrol. Geol. 52, 57-76.

Drivaliari, A., 1993. Images polliniques et paléoenvironnements au néogène supérieur en Méditerranée orientale. Aspects climatiques et paléogéographiques d'un transect latitudinal (de la Roumanie au Delta du Nil) (PhD Thesis). Univ. Montpellier 2, p. 333.

Dumurdzanov, N., Serafimovski, T., Burchfiel, B.C., 2004. Evolution of the NeogenePleistocene Basins of Macedonia. Geol. Soc. Amer. Digital Maps and Chart Series 1, accompanying notes, p. 20.

Dumurdzanov, N., Serafimovski, T., Burchfiel, B.C., 2005. Cenozoic tectonics of Macedonia and its relation to the South Balkan extensional regime. Geosphere 1(1), 1-22, doi: 10.1130/GES00006.1.

Gillet, S., Geissert, F., 1971. La faune de mollusques du Pontien de trilophos (SW Thessaloniki). Ann. Géol. Pays Hellén. Ser. 1, 23, 123-164.

Grothe, A., Sangiorgi, F., Mulders, Y.R., Vasiliev, I., Reichart G.-J., Brinkhius, H., Stoica, M., Krijgsman, W., 2014. Black Sea desiccation during the Messinian Salinity Crisis: Fact or fiction? Geology 42(7), 563-566. 
Hsü, K.J., 1978. Stratigraphy of the lacustrine sedimentarion in the Black Sea. In: Ross, D.A., Neprochnov, Y.P., et al. (Eds.), Initial Report of the Deep Sea Drilling Project, vol. 42(2), pp. 509-524.

Hsü, K.J., Montadert, L., Bernoulli, D., Cita, M.B., Erickson, A., Garrison, R.E., Kidd, R.B., Mélières, F., Müller, C., Wright, R. 1977. History of the Mediterranean salinity crisis. Nature 267, 399-403.

Hsü, K.J., Montadert, L., Bernoulli, D., Bizon, G., Cita, M.B., Erickson, A., Fabricius, F., Garrison, R.E., Kidd, R.B., Mélières, F., Müller, C., Wright, R.C., 1978a. Site 378: Cretan Basin. In: Hsü, K.J., Montadert, L. et al. (Eds.), Initial Report of the Deep Sea Drilling Project, vol. 42(1), pp. 321-357.

Hsü, K.J., Montadert, L., Bernoulli, D., Cita, M.B., Erickson, A., Garrison, R.E., Kidd, R.B., Mélières, F., Müller, C., Wright, R. 1978b. History of the Mediterranean Salinity Crisis. In: Ross, D.A., Neprochnov, Y.P., et al. (Eds.), Initial Report of the Deep Sea Drilling Project, vol. 42(2), pp. 1053-1078.

Iaccarino, S., 1985. Mediterranean Miocene and Pliocene planktic foraminifera. In: Bolli, H.M., Saunders, J.B., Perch-Nielsen, K. (Eds.), Plankton Stratigraphy, vol. 1. Cambridge University Press, Cambridge, pp. 283-314.

Jiménez-Moreno, G., 2005. Utilización del análisis polínico para la reconstrucción de la vegetación, clima y estimación de paleoaltitudes a lo largo de arco alpino europeo durante el Miocene (21-8 Ma) (PhD Thesis). Univ. Lyon 1 and Granada, p. 318.

Jiménez-Moreno, G., Popescu, S.-M., Ivanov, D., Suc, J.-P., 2007. Neogene flora, vegetation and climate dynamics in southeastern Europe and the northeastern Mediterranean. Micropalaeontol. In: Williams, M., Haywood, A.M., Gregory, F.J., Schmidt, D.N. (Eds.), Deep-Time Perspectives on Climate Change: Marrying the Signal from Computer Models and Biological Proxies, Soc., Spec. Publ., Geol. Soc. London, pp. 503-516.

Jipa, D.C., Olariu, C., 2013. Sediment routing in a semi-enclosed epicontinental sea: Dacian Basin, Paratethys domain, late Neogene, Romania. Global Planet. Change 103, 193-206.

Kamenov, B., Kojumdgieva, E., 1983. Stratigraphy of the Neogene in the Sofia basin. Palaeontology, Stratigraphy and Lithology, Sofia 18, 66-82 (in Bulgarian, with English summary).

Karakaş, Ç., 2012. Propagation et évolution structurale de la faille nord-anatolienne dans la région de Marmara (PhD Thesis). Univ. Diderot - Paris 7, p. 188.

Karistineos, N.K., Georgiades-Dikeoulia, E., 1985-1986. The marine transgression in the Serres Basin. Ann. Géol. Pays Hellén. Ser. 1, 33(1), 221-232.

Karistineos, N., Ioakim, C., 1989. Palaeoenvironmental and palaeoclimatic evolution of the Serres Basin (N. Greece) during the Miocene. Palaeogeogr., Palaeoclimatol., Palaeoecol. 70, 275-285.

Kloosterboer-van Hoeve, M.L., Steenbrink, J., Brinkhuis, H., 2001. A short-term cooling event, 4.205 million years ago, in the Ptolemais Basin, northern Greece. Palaeogeogr., Palaeoecol., Palaeoclimatol. 173, 61-73.

Kojumdgieva, E., 1987. Evolution géodynamique du bassin Egéen pendant le Miocène supérieur et ses relations à la Paratéthys Orientale. Geol. Balcanica 17(1), 3-14.

Kovačić, M., Zupanič, J., Babić, L., Vrsaljko, D., Miknić, M., Bakrač, K., Hećimović, I., Avanić, R., Brkić, M., 2004. Lacustrine basin to delta evolution in the Zagorje Basin, a Pannonian sub-basin (Late Miocene: Pontian, NW Croatia). Facies 50, 19-33.

Kräutner, H.G., Krstić, B., 2003. Geological map of the Carpatho - Balkanides between Mehadia, Oraviţa, Niš and Sofia. Geoinstitut, Belgrade.

Krijgsman, W., Stoica, M., Vasiliev, I., Popov V.V., 2010. Rise and fall of the Paratethys Sea during the Messinian Salinity Crisis. Earth. Planet. Sci. Lett. 290, 183-191. 
Krstić, N., 2006. Pliocene ostracodes of the Paludinian Beds in Pannonian Plain, Serbian Part. The Natural History Museum and Society "Nauka I društvo" Srbije (eds.), Belgrade, p. 409.

Krstić, N., Savić, L., Jovanović, G., 2012. The Neogene Lakes on the Balkan Land. Ann. géol. pays Balk. 73, 37-60.

Leever, K.A., Matenco, L., Rabagia, T. Cloetingh, S., Krijgsman, W., Stoica, M., 2010. Messinian sea level fall in the Dacic Basin (Eastern Paratethys): palaeogeographical implications from seismic sequence stratigraphy. Terra Nova 22, 12-17.

Lourens, L.J., Hilgen, F.J., Laskar, J., Shackleton, N.J., Wilson, D., 2005. The Neogene period. In: Gradstein, F.M., Ogg, J.G., Smith, A.G. (Eds.), A geological Time Scale 2004. Cambridge University Press, Cambridge, pp. 409-440.

Martini, E., 1971. Standard Tertiary and Quaternary calcareous nannoplankton zonation. In: Farinacci, A. (Ed.), Proceedings of the 2nd International Conference on Planktonic Microfossils, Roma 1970, vol. 2. Editura Tecnoscienza, Rome, pp. 739-785.

Mărunţeanu, M., Papaianopol, I., 1995. The connection between the Dacic and Mediterranean Basins based on calcareous nannoplankton assemblages. Rom. Journ. Stratigr. 76(7), 169-170.

Mărunţeanu, M., Papaianopol, I., 1998. Mediterranean calcareous nannoplankton in the Dacic Basin. Rom. Journ. Stratigr. 78, 115-121.

Melinte-Dobrinescu, M.C., Suc, J.-P., Clauzon, G., Popescu, S.-M., Armijo, R., Meyer, B., Biltekin, D., Çağatay, M.N., Ucarkus, G., Jouannic, G., Fauquette, S., Çakir, Z., 2009. The Messinian Salinity Crisis in the Dardanelles region: Chronostratigraphic constraints. Palaeogeogr., Palaeoclimatol., Palaeoecol., 278, 24-39.

Ognjanova-Rumenova, N., 2005. Upper Neogene siliceous microfossils from Pelagonia Basin (Balkan Peninsula). Geol. Carpathica 56(4), 347-358.

Ognjanova-Rumenova, N., 2006. Some aspects and problems concerning diatom biochronology for the Neogene in the region of the Balkan Peninsula. In: Witkowki, A. (Ed.), Eighteenth International Diatom Symposium, Miedzyzdroje, Poland. Biopress Limited, Bristol, pp. 337-345.

Ognjanova-Rumenova, N., Yaneva, M., Nikolov, G., 2007. Neogene Lake Basins in Southwestern Bulgaria - biostratigraphy, palaeoecology and diatom floristic interrelations. Geol. Balcanica 36(3-4), 57-61.

Ognjanova-Rumenova, N., Yaneva, M., Botev, I., 2008. Paleoecological development of the Sofia Neogene Basin (Southwestern Bulgaria) based on sedimentological and paleontological evidence. Geol. Carpathica 59(1), 59-70.

Pavlovic, M.B., 1985. S. Moravian freshwater basins and Intracarpathian basins (Niš Basin), YU. In: Steininger, F.F., Senes, J., Kleemann, K., Rögl, F., Neogene of the Mediterranean Tethys and Paratethys, Univ. Vienna, 1, p. 79-80, and 2, p. 459.

Perch-Nielsen, K., 1985. Cenozoic calcareous nannofossils. In: Bolli, H.M., Saunders, J.B., Perch-Nielsen, K. (Eds.), Plankton Stratigraphy, vol. 1. Cambridge University Press, Cambridge, pp. 427-554.

Popescu, S.-M., Biltekin, D., Winter, H., Suc, J.-P., Melinte-Dobrinescu, M.C., Klotz, S., Combourieu-Nebout, N., Rabineau, M., Clauzon, G., Deaconu, F., 2010. Pliocene and Lower Pleistocene vegetation and climate changes at the European scale: Long pollen records and climatostratigraphy. Quat. Intern. 219, 152-167.

Popescu, S.-M., Dalesme, F., Jouannic, G., Escarguel, G., Head, M.J., Melinte-Dobrinescu, M.C., Sütő-Szentai, M., Bakrac, K., Clauzon, G., Suc, J.-P., 2009. Galeacysta etrusca complex, dinoflagellate cyst marker of Paratethyan influxes into the Mediterranean Sea before and after the peak of the Messinian Salinity Crisis. Palynology 33(2), 105-134. 
Popescu, S.-M., Krijgsman, W., Suc, J.-P., Clauzon, G., Mărunţeanu, M., Nica, T., 2006. Pollen record and integrated high-resolution chronology of the Early Pliocene Dacic Basin (Southwestern Romania). Palaeogeogr., Palaeoclimatol., Palaeoecol. 238(1-4), 78 90.

Popov, S.V., Shcherba, I.G., Ilyina, L.B., Nevesskaya, L.A., Paramonova, N.P., Khondkarian, S.O., Magyar, I., 2006. Late Miocene to Pliocene palaeogeography of the Paratethys and its relation to the Mediterranean. Palaeogeogr., Palaeoclimatol., Palaeoecol. 238, 91-106.

Proedrou, P., Papaconstantinou, C.M., 2004. Prinos Basin - A model for oil exploration. Bull. Geol. Soc. Greece 36, 327-333.

Proedrou, P., Sidiropoulos, T., 1993. Prinos Field-Greece, Aegean Basin. In: Foster, N.H., Beaumont, E.A. (Eds.), Treatise of Petroleum Geology, Atlas of Oil and Gas Fields. Amer. Assoc. Petrol. Geol., Tulsa, Oklahoma, pp. 275-291.

Psilovikos, A., Karistineos, N., 1986. A depositional sedimentary model for the Neogene uraniferous lignites of the Serres graben, Greece. Palaeogeogr., Palaeoclimatol., Palaeoecol. 56, 1-16.

Raffi, I., Backman, J., Fornaciari, E., Pälike, H., Rio, D., Lourens, L., Hilgen, F., 2006. A review of calcareous nannofossil astrobiochronology encompassing the past 25 million years. Quat. Sci. Rev. 25, 3113-3137.

Rögl, F., Steininger, F.F., 1983. Vom Zerfall der Tethys zu Mediterran und Paratethys. Die neogene Paläogeographie und Palinspastik des zirkum-mediterranen Raumes. Ann. Naturhist. Mus. Wien 85(A), 135-163.

Ryan, W.B.F., S.M. Carbotte, J.O. Coplan, S. O'Hara, A. Melkonian, R. Arko, R.A. Weissel, V. Ferrini, A. Goodwillie, F. Nitsche, J. Bonczkowski, and R. Zemsky (2009), Global Multi-Resolution Topography synthesis, Geochem. Geophys. Geosyst. 10, Q03014, doi:10.1029/2008GC002332.

Schuster, J.M., Auxietre, J.-L., Biju-Duval, B., Letouzey, J., 1978. CIDOG Mer Egée/Mer de Crète. Rapport CFP-IFP, p. 63.

Sidiropoulos, D., 1980. Geologie der Griechischen Tertiärbecken Nestos-Prinos und XantiKomotini. Sonderveröff. geol. Inst. Univ. Köln 39, p. 158.

Snel, E., Mărunţeanu, M., Macaleţ, R., Meulenkamp J.E., van Vugt, N., 2006a. Late Miocene to Early Pliocene chronostratigraphic framework for the Dacic Basin, Romania. Palaeogeogr., Palaeoclimatol., Palaeoecol. 238, 107-124.

Snel, E., Mărunţeanu, M., Meulenkamp, J.E., 2006b. Calcareous nannofossil biostratigraphy and magnetostratigraphy of the Upper Miocene and Lower Pliocene of the Northern Aegean (Orphanic Gulf-Strimon Basin areas), Greece. Palaeogeogr., Palaeoclimatol., Palaeoecol. 238, 125-150.

Soria, J.M., Caracuel, J.E., Corbí, H., Dinarès-Turell, J., Lancis, C., Tent-Manclús, J.E., Viseras, C., Yébenes, A., 2008. The Messinian-early Pliocene stratigraphic record in the southern Bajo Sedura Basin (Betic Cordillera, Spain): Implications for the Mediterranean salinity crisis. Sedim. Geol. 203, 267-288.

Spassov, N., Tzankov, T., Geraads, D., 2006. Late Neogene stratigraphy, biochronology, faunal diversity and environments of South-west Bulgaria (Struma river valley). Geodiversitas 28(3), 477-498.

Sprovieri, M., Ribera d'Alcalà, M., Manta, D.S., Bellanca, A., Neri, R., Lirer, F., Taberner, C., Pueyo, J.J., Sammartino, S., 2008. Ba/Ca evolution in water masses of the Mediterranean late Neogene. Paleoceanography 23(PA3205), doi:10.1029/2007PA001469.

Steenbrink, J., Hilgen, F.J., Krijgsman, W., Wijbrans, J.R., Meulenkamp, J.E., 2006. Late Miocene to Early Pliocene depositional history of the intramontane Florina-Ptolemais- 
Servia Basin, NW Greece: Interplay between orbital forcing and tectonics. Palaeogeogr., Palaeoclimatol., Palaeoecol. 238, 151-178.

Steffens, P., de Bruijn, H., Meulenkamp, J.E., Benda, L., 1979. Field guide to the neogene of Northern Greece (Thessaloniki area and Strimon Basin). Publ. Department Geol. Paleontol. Univ. of Athens Ser. A, 35, p. 14.

Stevanović, P., Škerlj, Ž., 1989. The Pontian sediments in Slovenia. In: Malez, M., Stevanović, P. (Eds.), Pontian, Chronostratigraphie und Neostratotypen, Neogene der Westlichen Paratethys, 8, JAZU, SANU, Zagreb - Belgrade, p. 153-179.

Stoica, M., Lazăr, I., Krijgsman, W., Vasiliev, I., Jipa, D., Floroiu, A., 2013. Paleoenvironmental evolution of the East Carpathian foredeep during the late Mioceneearly Pliocene (Dacian Basin; Romania). Global Planet. Change 103, 135-148.

Suc, J.-P., Do Couto, D., Melinte-Dobrinescu, M.C., Macaleţ, R., Quillévéré, F., Clauzon, G., Csato, I., Rubino, J.-L., Popescu, S.-M., 2011. The Messinian Salinity Crisis in the Dacic Basin (SW Romania) and early Zanclean Mediterranean - Paratethys high sea-level connection. Palaeogeogr., Palaeoclimatol., Palaeoecol. 310, 256-272.

Suc, J.-P., Gillet, H., Çağatay, M.N., Lericolais, G., Armijo, R., Melinte-Dobrinescu, M.C., Şen, Ş., Clauzon, G., Sakinç, M., Zabcı, C., Ucarkus, G., Meyer, B., Çakir, Z., Karakaş, Ç., Popescu, S.-M., Jouannic, G., Macaleţ, R., revised. The region of the Strandja Sill (North Turkey) and the Messinian events. Mar. Petrol. Geol., this issue.

Syrides, G.E., 1998a. Neogene marine cycles in Strymon basin, Macedonia, Greece. Geol. Soc. Greece, Spec. Publ. 9, 217-225.

Syrides, G.E., 1998b. Paratethyan mollusc faunas from the Neogene of Macedonia and Thrace, Northern Greece. Rom. J. Stratigr. 78, 171-180.

Vasiliev, I., Krijgsman, W., Langereis, C.G., Panaiotu, C.E., Maţenco, L., Bertotti, G., 2004. Towards an astrochronological framework for the eastern Paratethys Mio-Pliocene sedimentary sequences of the Focşani basin (Romania). Earth Planet. Sci. Lett. 227, 231247.

Westaway, R., 2006. Late Cenozoic extension in SW Bulgaria: a synthesis. Geol. Soc. London, Spec. Publ. 260, 557-590.

Winter, A., Jordan, R.W., Roth, P.H., 1994. Biogeography of living coccolithophores in ocean waters. In: Winter, A., Siesser, W.G. (Eds.), Coccolithophores, CambridgeUniversity Press, Cambridge, pp. 161-177.

Zagorčev, I., 1992a. Neotectonic development of the Struma (Kraistid) Lineament, southwest Bulgaria and northern Greece. Geol. Magazine 129(2), 197-222.

Zagorčev, I., 1992b. Neotectonics of the central parts of Balkan Peninsula: basic features and concepts. Geol. Rundschau 81(3), 635-654.

Zagorchev, I., 2007. Late Cenozoic development of the Strouma and Mesta fluviolacustrine systems, SW Bulgaria and northern Greece. Quat. Sci. Rev. 26, 2783-2800. 

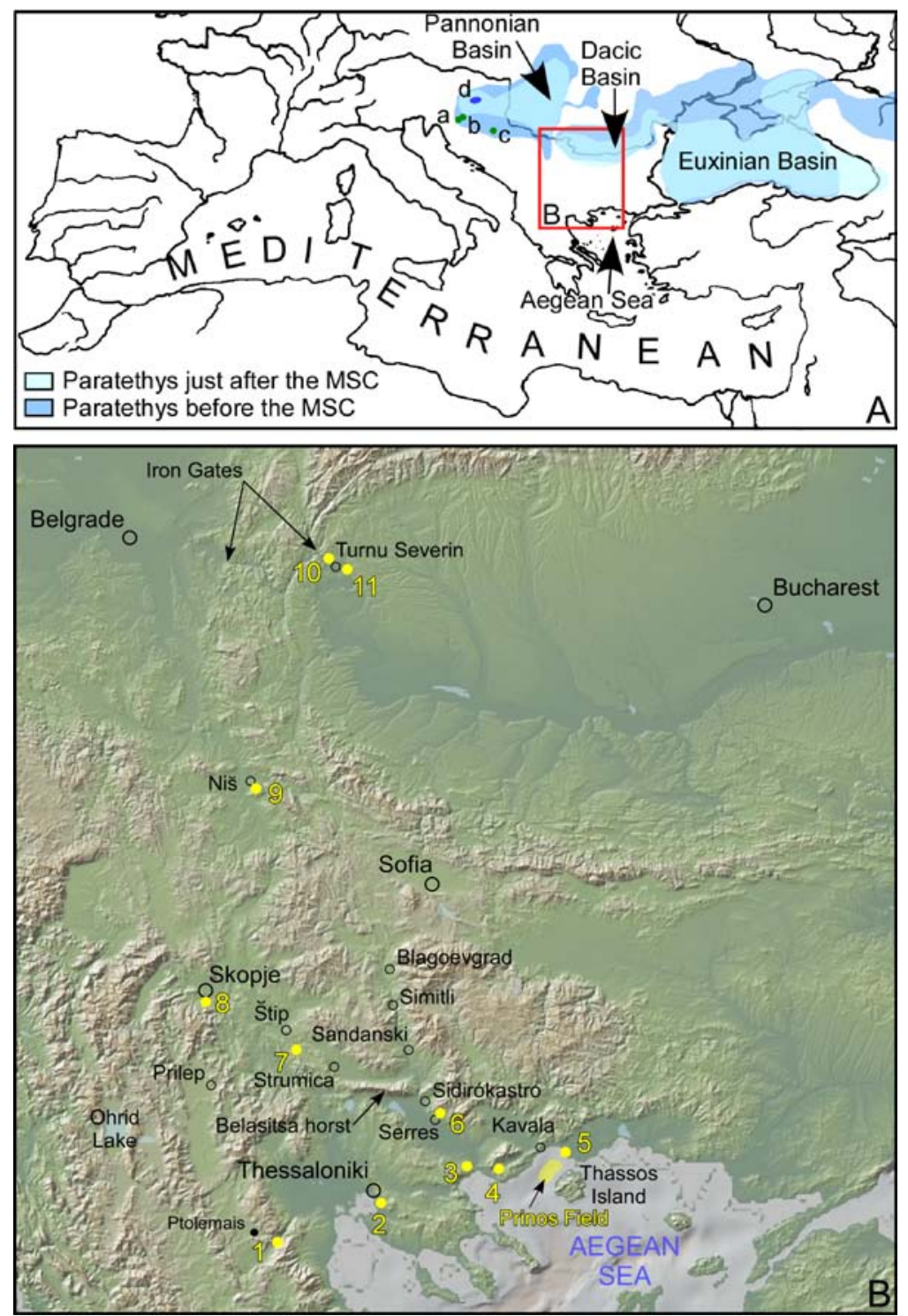

Fig. 1. Location maps.

A, Location of the study area.

Palaeogeography of the Central and Eastern Paratethys before and just after the Messinian Salinity Crisis is from Krijgsman et al. (2010), modified. Proposed gateway(s), subject of this paper, are not shown.

Pannonian - Early Pontian quoted localities: a, Krašić; b, Malunje; c, Krajačići.

Pannonian - Late Pontian quoted locality: d, Mura-Zala Basin.

B, Studied localities.

1, Prosilio; 2, Trilophos; 3, Amphipolis Lion; 4, Akropotamos; 5, Nestos 1 and 2 wells; 6, Serres; 7, Lakavica; 8, Dračevo; 9, Gabrovačka; 10, Gura Vaii - Turnu Severin ; 11, Hinova.

Relief is from GeoMapApp@ System http://www.geomapapp.org/ (Ryan et al., 2009). 


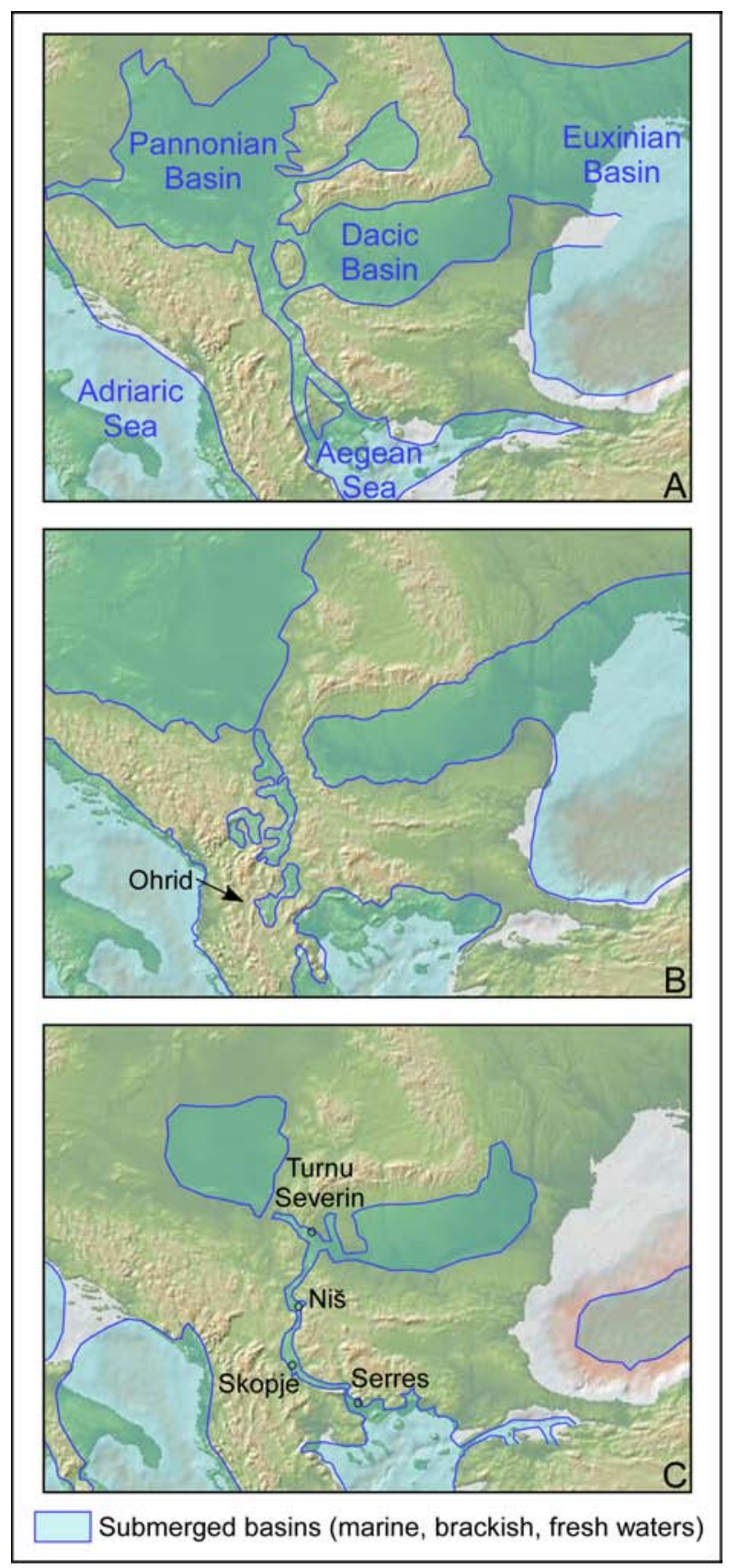

Fig. 2. Previously mapped gateways within the Balkans.

A, According to Hsü (1978).

B, According to Hsü et al. (1977, 1978b).

C, According to Bache et al. (2012).

Relief is from GeoMapApp(C System http://www.geomapapp.org/ (Ryan et al., 2009). 


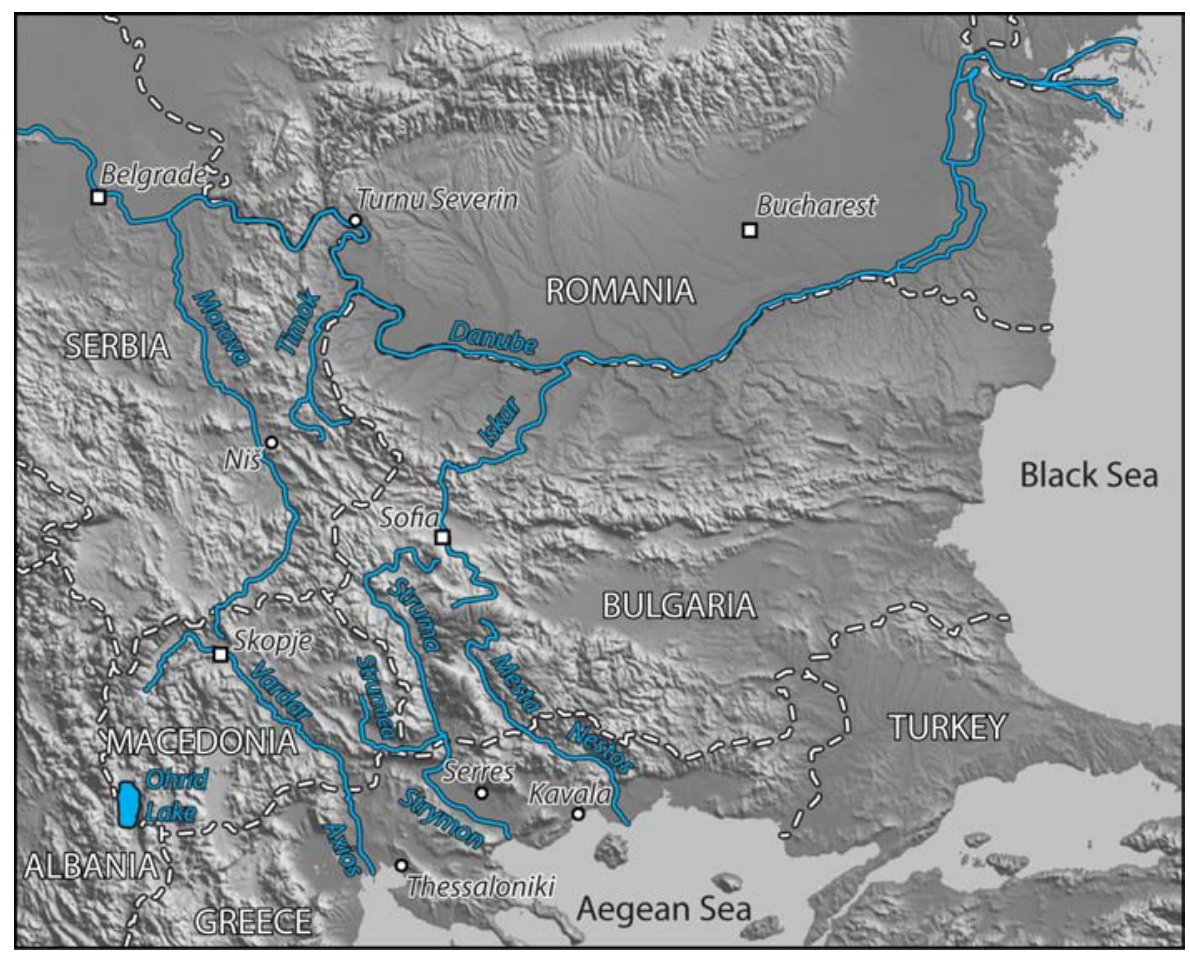

Fig. 3. Present-day fluvial network in the Balkans region, with opposed drainage in direction of the Aegean Sea on the one hand, of the Danube River on the other hand.

Relief is from GeoMapApp@ System http://www.geomapapp.org/ (Ryan et al., 2009).

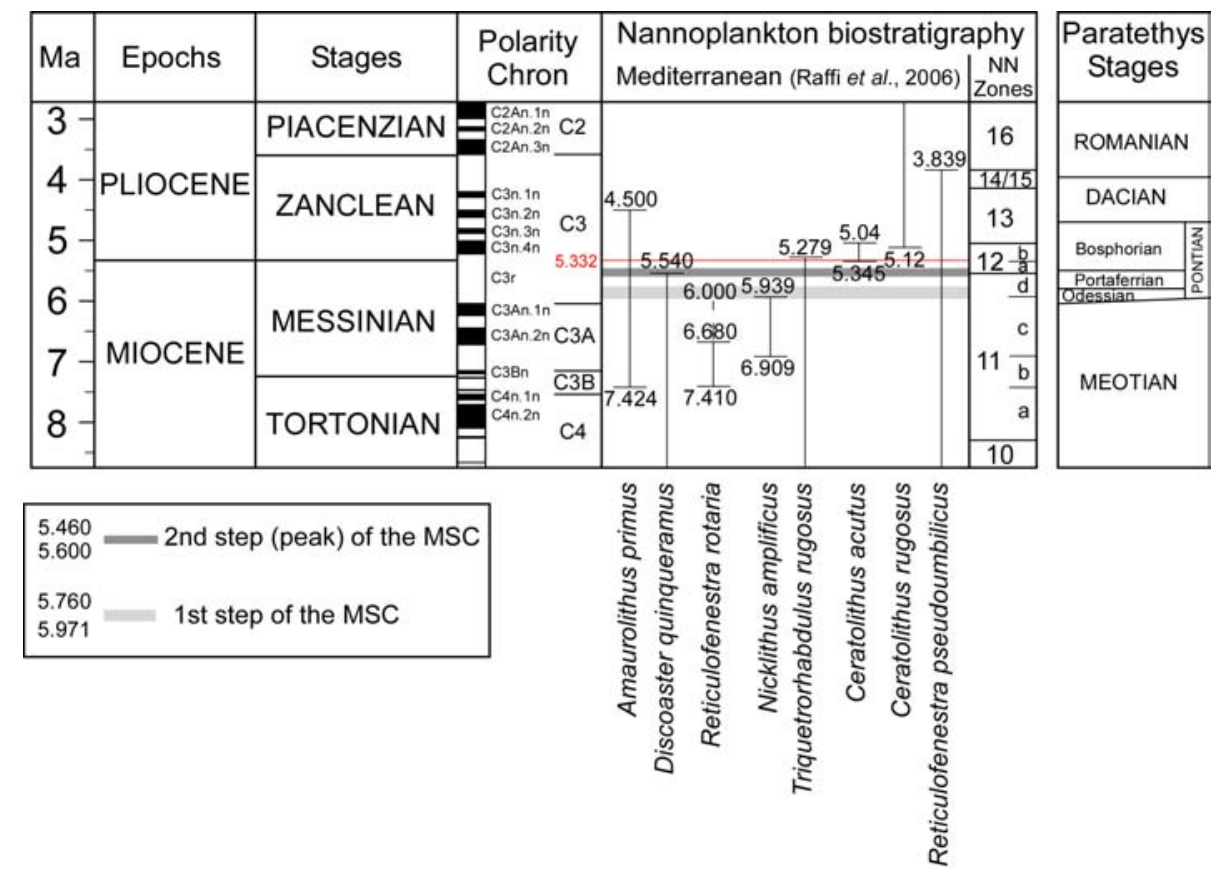

Fig. 4. Standard global nannoplankton bio-chronostratigraphy (Raffi et al., 2006) with respect to the Global Polarity Time Scale (Lourens et al., 2004) from 8.5 to 3 Ma. NN Zones are from Martini (1971) amended by Perch-Nielsen (1985) and Berggren et al. (1995). See also Melinte-Dobrinescu et al. (2009) for more details concerning this nannoplankton chart.

Correlations with Paratethys Stages are from Vasiliev et al. (2004) and Krijgsman et al. (2010). 


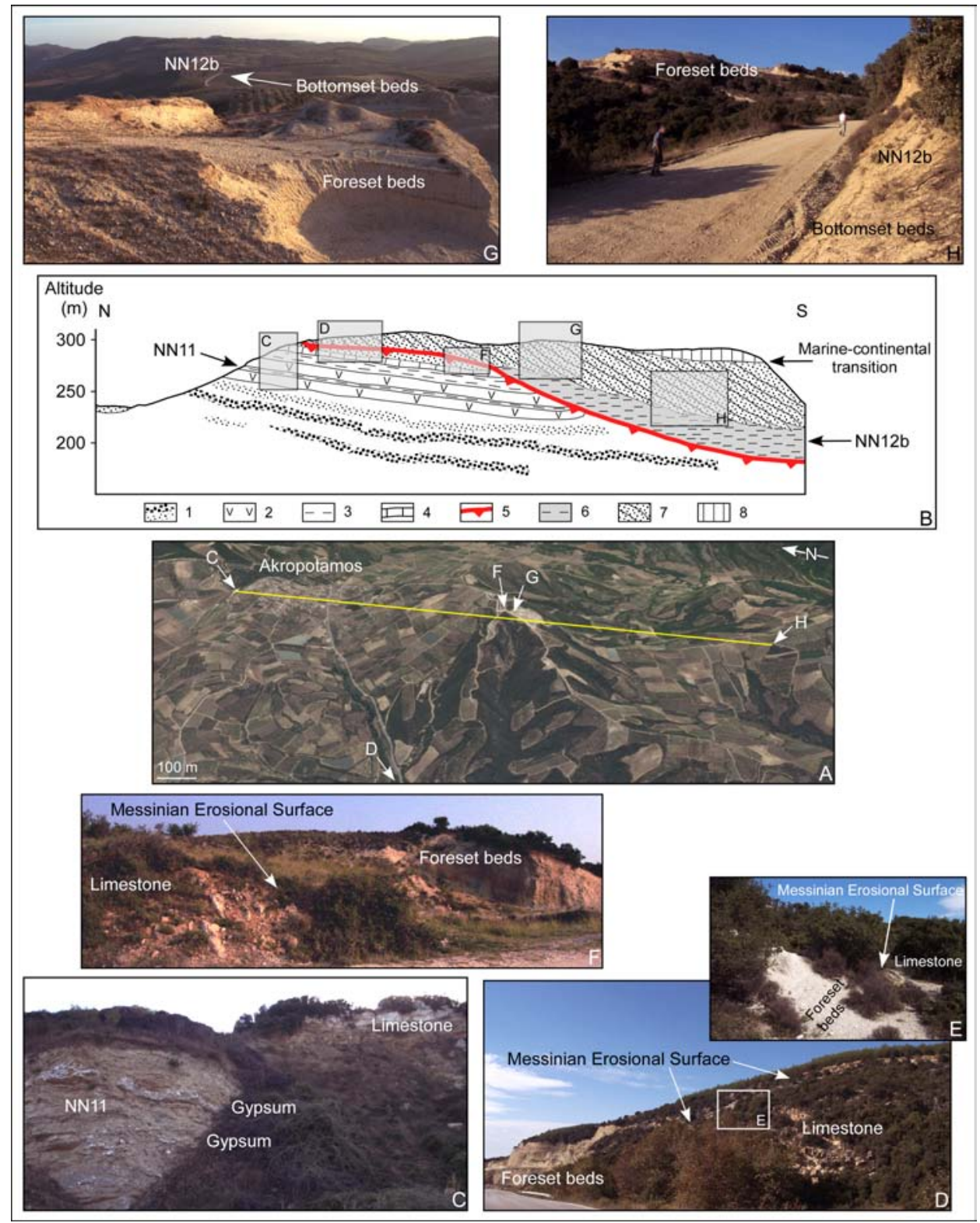

Fig. 5. Record of the MSC at Akropotamos (Northern Aegean).

A, GoogleEarth three-dimensional view showing the location of the studied section (yellow line) and localities near Akropotamos (relief is exaggerated three times).

$\mathrm{B}$, Interpretative sketch of the Akropotamos section.

1, Miocene continental deposits (sands, conglomerates);

Messinian: 2, Gypsums; 3, Clays; 4, Limestones;

5, Messinian Erosional Surface;

Post-MSC Gilbert-type fan delta: 6, Clayey bottomset beds; 7, Sandy and conglomeratic foreset beds; 8 , Topset beds (limestone).

C, Gypsum quarry northward of Akropotamos.

D, The Messinian Erosional Surface separating the Gilbert-type fan delta foreset beds from the Messinian limestone along the road to Kariani.

E, Detail of this contact.

F, The Messinian Erosional Surface separating the Gilbert-type fan delta foreset beds from the Messinian limestone southward of Akropotamos.

G, Proximal part of the Akropotamos Gilbert-type fan delta.

H, Distal part of the Akropotamos Gilbert-type fan delta. 


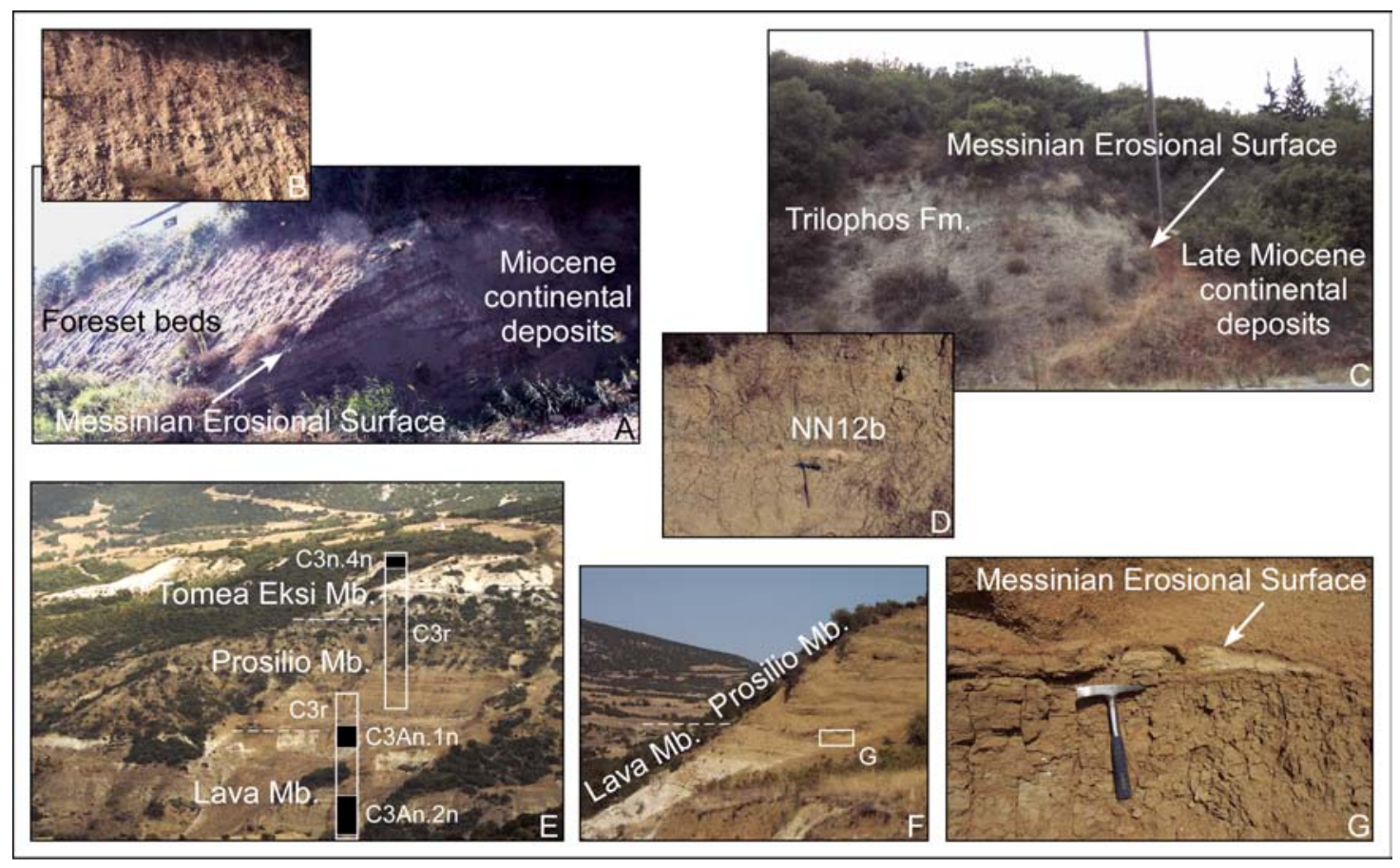

Fig. 6. Examples of the Messinian Erosional Surface.
A, Near the statue of the Amphipolis Lion.
$B$, Detail of the foreset beds at the same place.
C, Near Trilophos.
D, Marine clays topping the Trilophos Formation at the same place.
E, View of the middle part of the Prosilio section.
$F$, Detail of the same section.
G, Detail of photograph F.

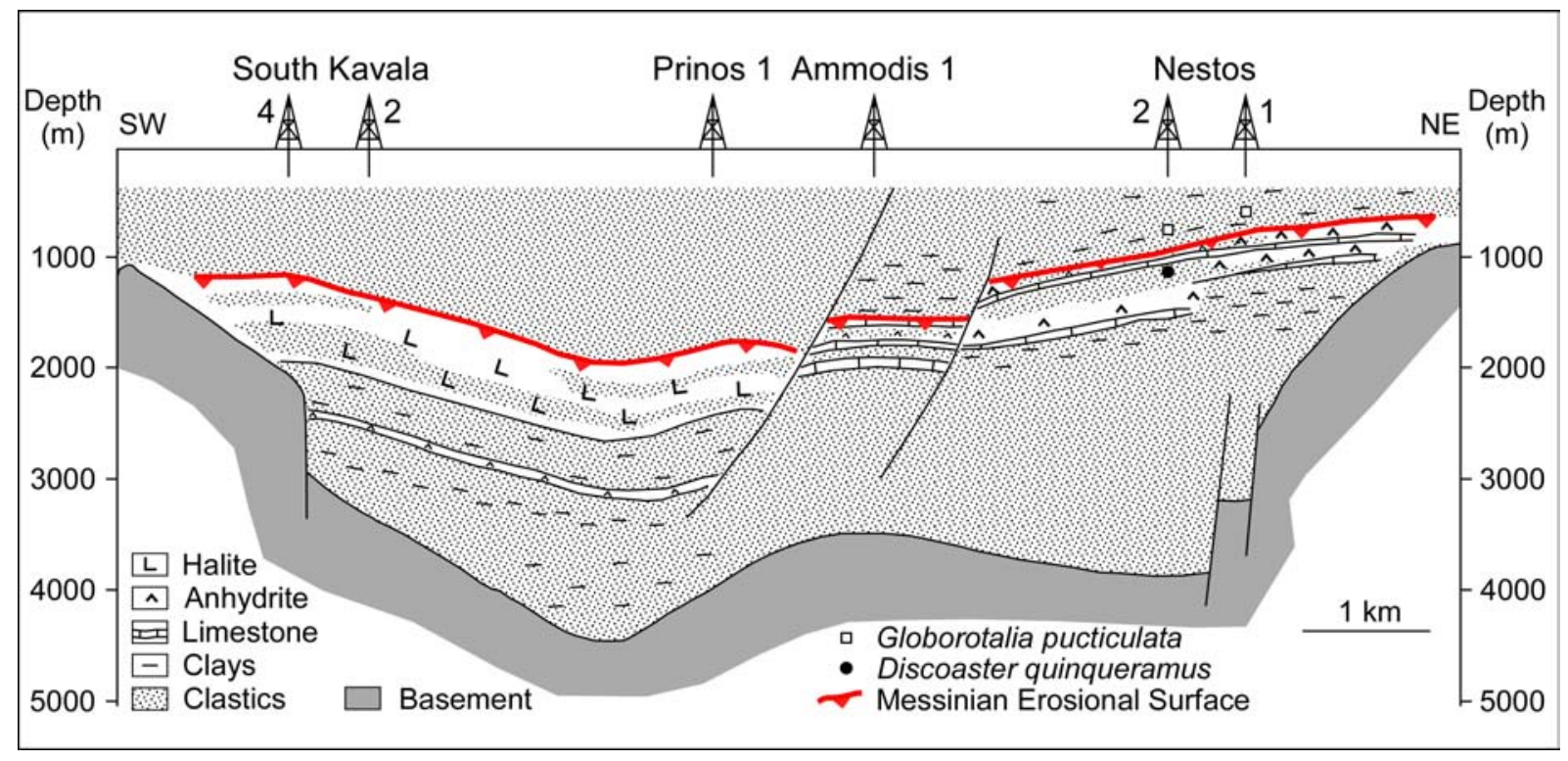

Fig. 7. Re-interpreted synthetic section through the Prinos hydrocarbon field (from Proedrou and Sidiropoulos, 1993). 


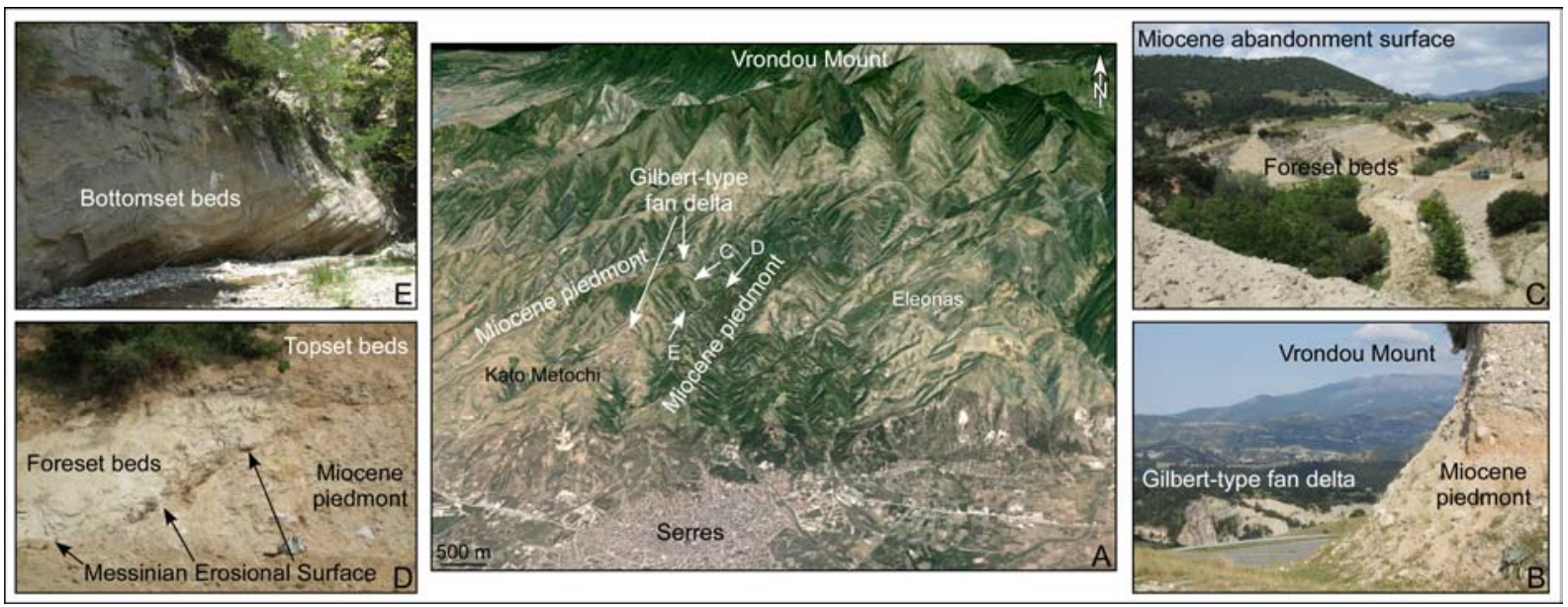

Fig. 8. The Serres area.

A, GoogleEarth three-dimensional view showing the location of the Serres Zanclean Gilbert-type fan delta nested within the Miocene piedmont of the Vrondou Mount (relief is exaggerated three times).

B, View of the foreset beds of the Serres Zanclean Gilbert-type fan delta nested within the Miocene piedmont.

C, Zoom on the foreset beds of the Serres Zanclean Gilbert-type fan delta nested within the Miocene piedmont.

D, The Messinian Erosional Surface.

E, Bottomset beds with lignite beds of the Serres Zanclean Gilbert-type fan delta.

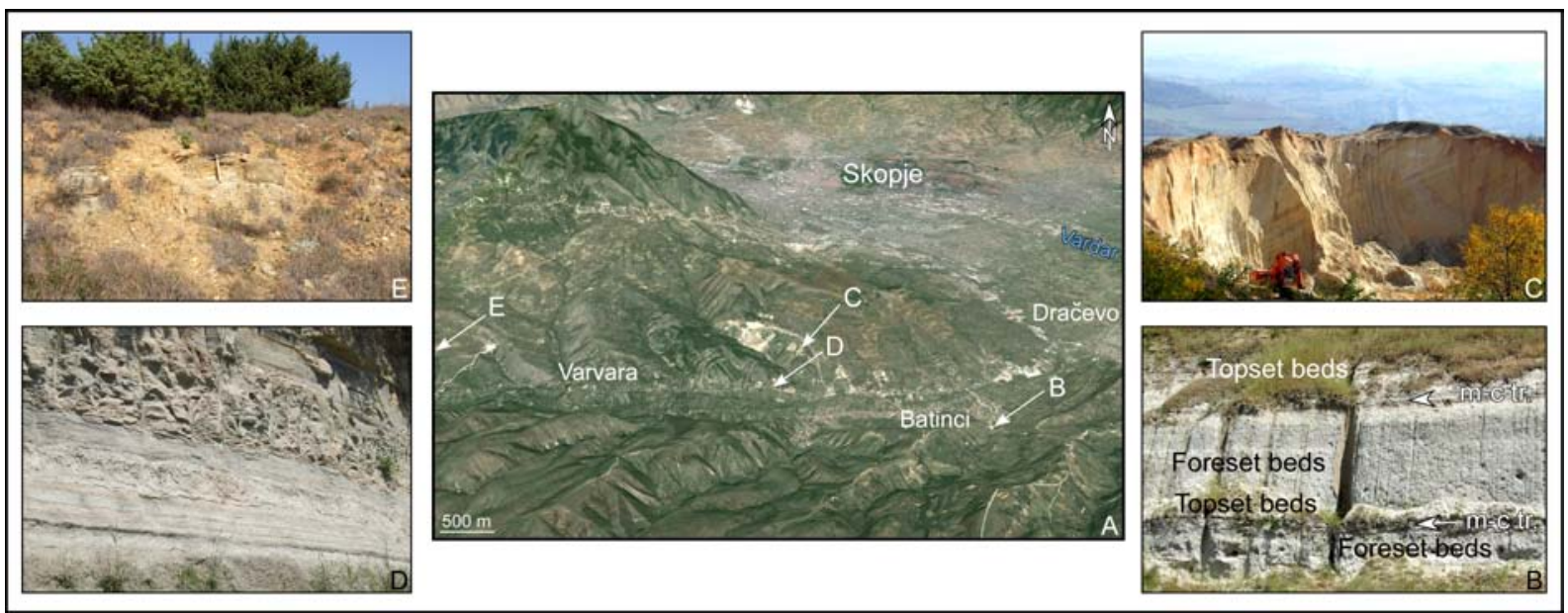

Fig. 9. The Dračevo Zanclean Gilbert-type fan delta.

A, Skopje area: GoogleEarth three-dimensional view showing the location of the Dračevo Zanclean Gilbert-type fan delta with exposed sections near Batinci and Varvara (relief is exaggerated three times).

$\mathrm{B}$, Double marine-continental transition.

C, Sandy to conglomeratic foreset beds.

D, Clayey bottomset beds.

E, Conglomeratic topset beds with travertine blocks. 

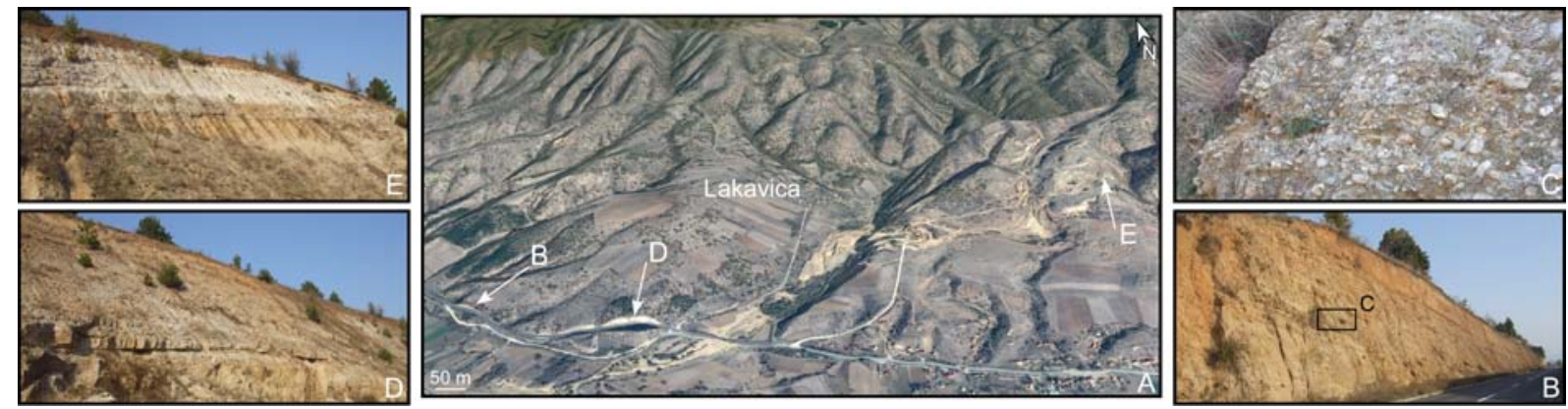

Fig. 10. The Lakavica series.

A, GoogleEarth three-dimensional view showing the location of the sections (relief is exaggerated three times).

B, Prograding deposits.

C, Detail of the conglomeratic prograding deposits.

D, Transition from prograding to aggrading deposits.

E, Aggrading deposits.

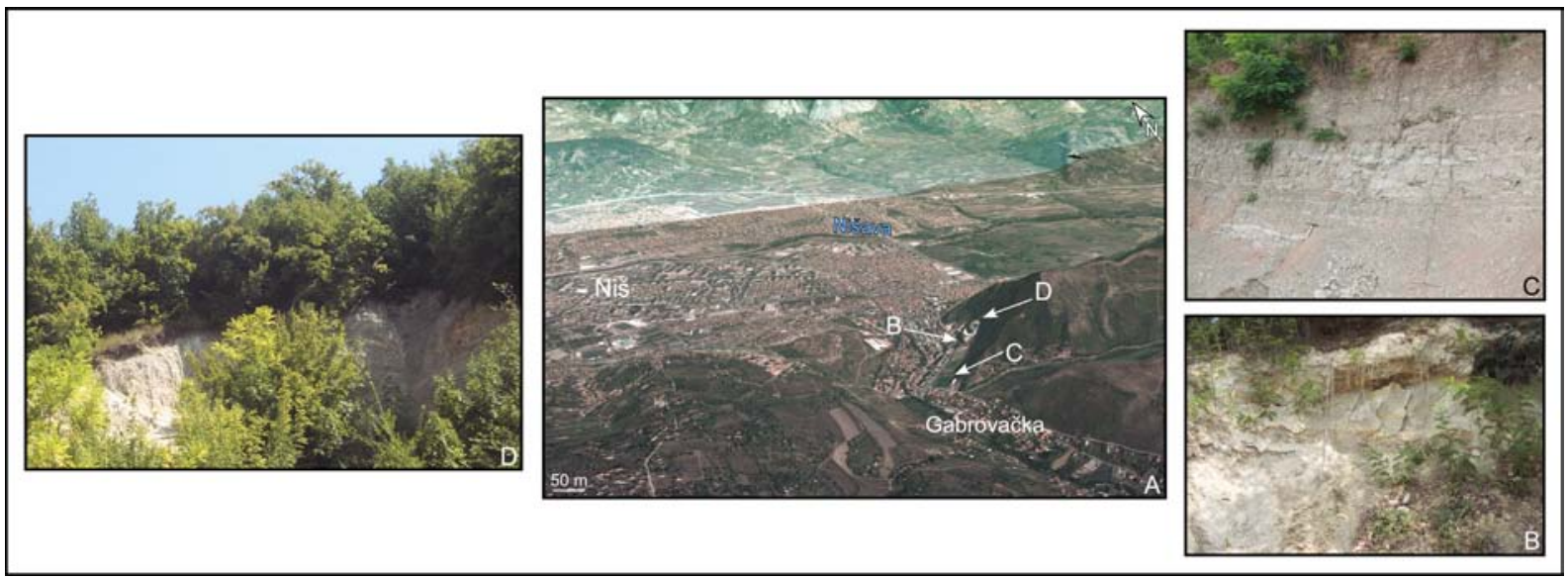

Fig. 11. The Niš area.

A, GoogleEarth three-dimensional view showing the location of the Gabrovačka sections (relief is exaggerated three times).

B, Clays with marine microfossils at Gabrovačka Reka.

C, Lacustrine clays back the Gabrovačka stadium.

D, Overlying fluvial conglomerates at Gabrovačka Reka. 


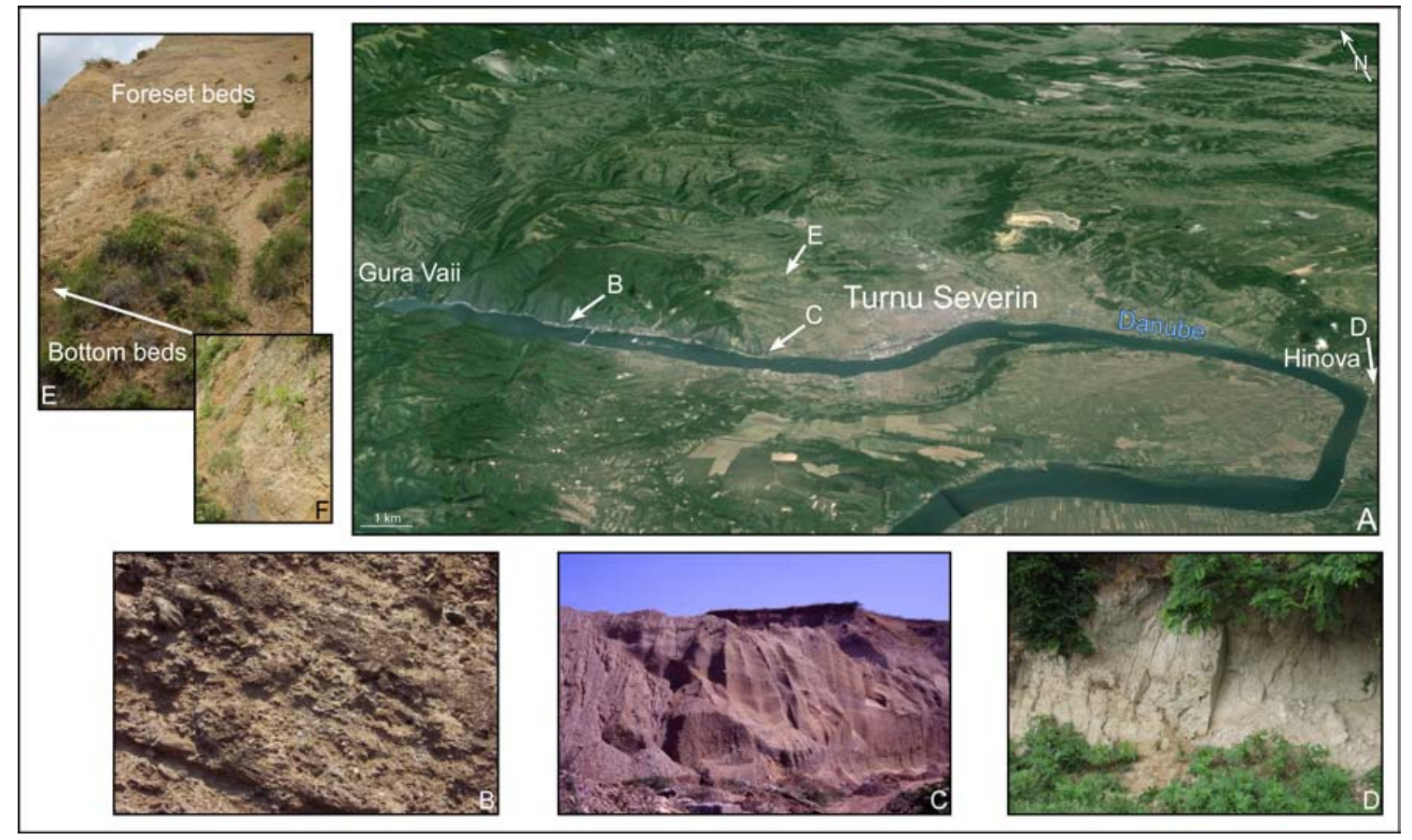

Fig. 12. Major features of the Turnu Severin Gilbert-type fan delta.

A, GoogleEarth three-dimensional view showing the location of the illustrated sections (relief is exaggerated three times).

$\mathrm{B}$, Detail of the conglomeratic foreset beds.

C, Gravely and sandy foreset beds.

D, Clayey bottomset beds.

$\mathrm{E}$, Interlocked bottomset and foreset beds at Pd. Trestenic.

F, Detail of the clayey bottomset beds.

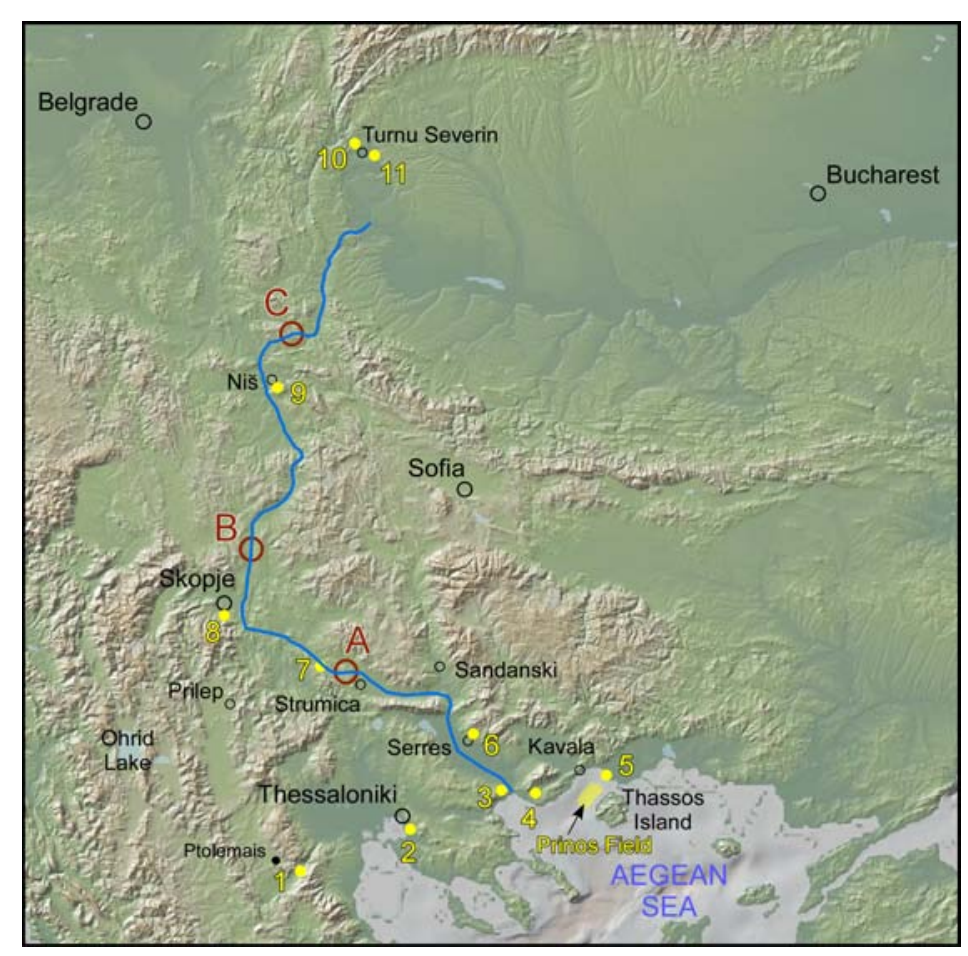

Fig. 13. Proposed course of the Balkans corridor with the present-day watersheds A, B, and C with respect to the Strymon, Vardar, Morava and Timok drainage basins, respectively (see Figure 3). 


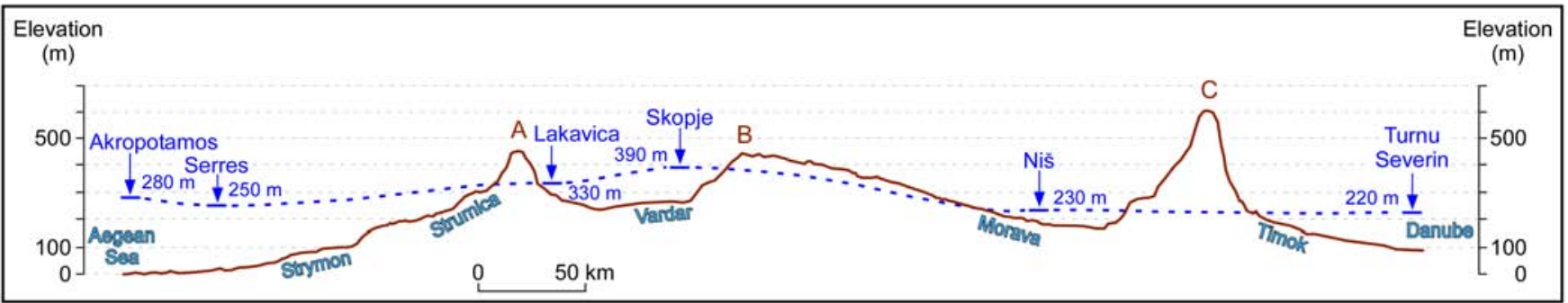

Fig. 14. Present-day altitudinal profile of the proposed Balkans corridor with highest places corresponding to the drainage divides (A, between the Strymon and Vardar systems; $\mathrm{B}$, between the Vardar and Morava systems; C, between the Morava and Timok systems) on which is reported the present-day altitude envelope (in blue) of the marine-continental transition (i.e., the Zanclean seashore) in the six evidenced Zanclean deltaic systems.

\begin{tabular}{|c|c|c|c|c|}
\hline Taxa $\quad$ Localities I & $\begin{array}{l}\text { Amphipolis } \\
\text { Lion }\end{array}$ & Trilophos & $\begin{array}{c}\text { Kato } \\
\text { Metochi }\end{array}$ & Batinci \\
\hline Rinus & 188 & 189 & 64 & 134 \\
\hline Pinus haploxylon type & & & & 1 \\
\hline Indeterminable Pinaceae & 66 & & 5 & 1 \\
\hline Cupressaceae & 1 & & 16 & 7 \\
\hline Ephedra & 1 & & 2 & \\
\hline Taxodium type & 2 & & 21 & 27 \\
\hline Other Taxodiaceae & 13 & 10 & 66 & 9 \\
\hline Arecaceae & & & 1 & 1 \\
\hline Nyssa & & & & 3 \\
\hline Sapotaceae & & & & 1 \\
\hline Engelhardia & 3 & 1 & & 5 \\
\hline Carya & 1 & 4 & & 18 \\
\hline Juglans & 1 & & & 2 \\
\hline Pterocarya & 3 & 4 & & \\
\hline Liquidambar & & & 7 & 3 \\
\hline Eucommia & & & & 1 \\
\hline Quercus (deciduous) & 13 & 32 & 19 & 7 \\
\hline Fagus & 3 & 4 & & 8 \\
\hline Castanea type & & & 1 & \\
\hline Acer & 1 & 3 & 1 & 1 \\
\hline Celtis & & & & 1 \\
\hline Ulmus & 2 & & & 1 \\
\hline Zelkova & 4 & 12 & 1 & 4 \\
\hline Alnus & & 31 & & 1 \\
\hline Betula & 1 & 10 & 3 & 1 \\
\hline Carpinus of. betulus & & & & 4 \\
\hline Carpinus cf. orientalis & & 4 & & 1 \\
\hline Corylus & & 1 & & \\
\hline Tilia & 1 & & & \\
\hline Salix & & 1 & & \\
\hline Populus. & 6 & & 2 & 2 \\
\hline Hedera & & & 1 & \\
\hline Ericaceae & & 1 & & \\
\hline Buxus sempervirens type & 1 & & & \\
\hline Quercus ilex type & 3 & & 1 & 4 \\
\hline Olea & & & & 1 \\
\hline Phillyrea & 1 & & & 1 \\
\hline Cathaya & 7 & & 7 & 12 \\
\hline Cedrus & 18 & 13 & 2 & 15 \\
\hline Tsuga & & 42 & 1 & \\
\hline Abies & 3 & 35 & 1 & \\
\hline Picea & 20 & & & \\
\hline $\begin{array}{l}\text { Amaranthaceae- } \\
\text { Chenopodiaceae }\end{array}$ & 8 & 20 & & 1 \\
\hline Caryophyllaceae & 2 & & & \\
\hline Poaceae & 22 & 49 & 3 & 5 \\
\hline Asteraceae Asteroideae & 1 & 3 & 1 & \\
\hline Asteraceae Cichoriojdeal & 4 & 11 & 1 & \\
\hline Artemisia & & 3 & & 1 \\
\hline Brassicaceae & 1 & & & \\
\hline Euphorbia & & & 1 & 1 \\
\hline Geranium & & 1 & & \\
\hline Cannabaceae & & & & 1 \\
\hline Campanulaceae & 1 & & & \\
\hline Convolvulus & & & & 1 \\
\hline Polygonum & & 1 & & \\
\hline Plantage & 1 & & & \\
\hline Rosaceae & 3 & & & \\
\hline Ranunculaceae & & 1 & & \\
\hline Cyperaceae & 3 & & & 1 \\
\hline Sparganium & & 16 & & \\
\hline Typha & & 2 & & \\
\hline Potamogeton & 1 & 1 & & 1 \\
\hline Indeterminate pollen & & 2 & & \\
\hline Indeterminable pollen & 26 & & 16 & 2 \\
\hline Reworked pollen & 3 & & 2 & \\
\hline Pterodophyte monolete spore & 8 & & 8 & 3 \\
\hline Pterodophyte trilete spore & 4 & & 10 & 5 \\
\hline Polypodiaceae & & & 1 & \\
\hline Osmunda & 1 & & & \\
\hline Other spore & 4 & & 6 & 2 \\
\hline Reworked spore & & & 2 & 4 \\
\hline Bryophyte spore & & & & 1 \\
\hline Fungus spore & 3 & & 3 & 5 \\
\hline Acritarch & & & 9 & 30 \\
\hline
\end{tabular}

Table 1. Results of some pollen analyses. 